\title{
CREDIT RISK
}

\section{TRANSFERS}

AND THE

\section{MACROECONOMY}

by Ester Faia 


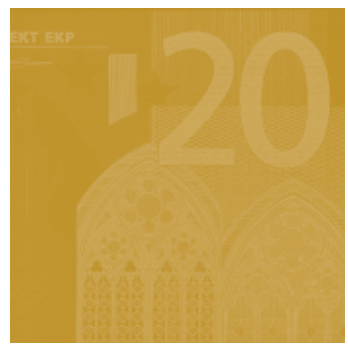

\title{
WORKING PAPER SERIES
}

NO I256 / OCTOBER 2010

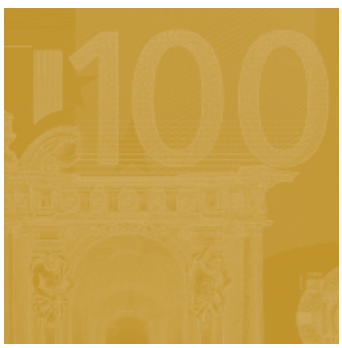

\author{
ECB LAMFALUSSY FELLOWSHIP \\ PROGRAMME \\ CREDIT RISK TRANSFERS \\ AND THE MACROECONOMY ${ }^{\prime}$
}

by Ester Faia ${ }^{2}$
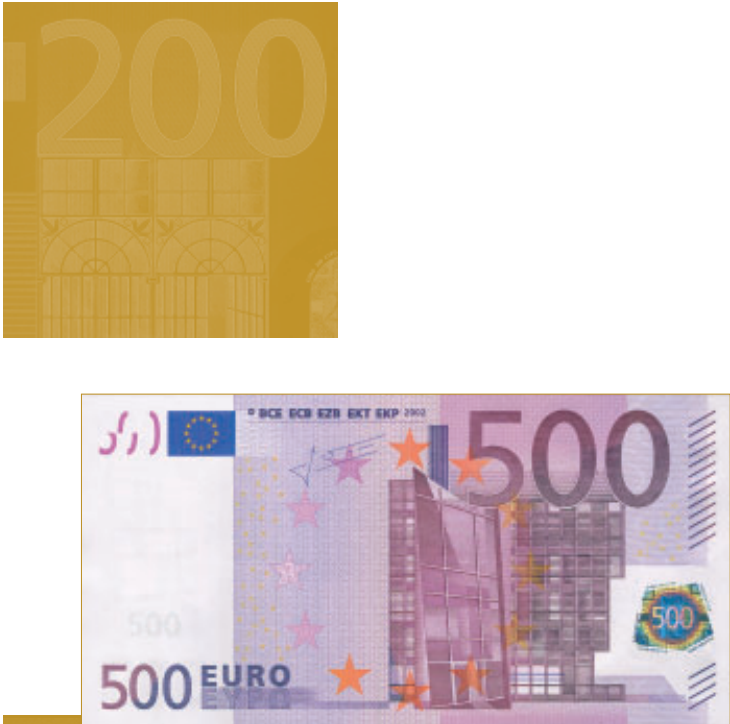

In 2010 all ECB publications feature a motif $€ 500$ banknote.

NOTE: This Working Paper should not be reported as representing the views of the European Central Bank (ECB). The views expressed are those of the authors and do not necessarily reflect those of the ECB.

This paper can be downloaded without charge from http://www.ecb.europa.eu or from the Social Science Research Network electronic library at http://ssrn.com/abstract_id= $168577 \mathrm{I}$.

\footnotetext{
I I gratefully acknowledge financial support from the Lamfalussy award of the European Central Bank. Ignazio Angeloni provided useful suggestions on an earlier draft. I thank participants at the: ECB conference on "The bank lending channel: new models and empirical analysis", Society for Computational Economics 2010 in London and at the macro seminar at Georgetown University. 2 Kiel IfW, CEPREMAP and Department of Money and Macro, Goethe University Frankfurt, House of Finance, office 3.47, Grueneburgplatz I, 60323, Frankfurt am Main, Germany; e-mail: faia@wiwi.uni-frankfurt.de. 


\section{Lamfalussy Fellowships}

This paper has been produced under the ECB Lamfalussy Fellowship programme. This programme was launched in 2003 in the context of the ECB-CFS Research Network on "Capital Markets and Financial Integration in Europe". It aims at stimulating high-quality research on the structure, integration and performance of the European financial system.

The Fellowship programme is named after Baron Alexandre Lamfalussy, the first President of the European Monetary Institute. Mr Lamfalussy is one of the leading central bankers of his time and one of the main supporters of a single capital market within the European Union.

Each year the programme sponsors five young scholars conducting a research project in the priority areas of the Network. The Lamfalussy Fellows and their projects are chosen by a selection committee composed of Eurosystem experts and academic scholars. Further information about the Network can be found at http://www.eufinancial-system.org and about the Fellowship programme under the menu point "fellowships".

\footnotetext{
(C) European Central Bank, 2010

Address

Kaiserstrasse 29

60311 Frankfurt am Main, Germany

Postal address

Postfach 160319

60066 Frankfurt am Main, Germany

Telephone

+496913440

Internet

http://www.ecb.europa.eu

Fax

+496913446000

All rights reserved.

Any reproduction, publication and reprint in the form of a different publication, whether printed or produced electronically, in whole or in part, is permitted only with the explicit written authorisation of the ECB or the author. 


\section{CONTENTS}

Abstract

Non-technical summary

1 Introduction

2 Micro-foundations from the banking and corporate finance literature

3 The model

4 Households

4.1 Final good firms

4.2 Monopolistic competitive firms

4.3 Capital good production

4.4 Banks

4.5 The financial contract in absence of secondary markets

4.6 The financial contract with secondary market for credit risk transfer

4.7 Households budget constraint with secondary markets

4.8 Consumption and asset accumulation for bankers and entrepreneurs

4.9 Aggregation

4.10 Monetary policy

4.11 Competitive equilibrium

4.12 The role of secondary market and the leverage ratios

4.13 Risk premia and efficiency wedges

4.14 Bank capital ratios

4.15 Calibration

5 Quantitative properties of the model in absence of secondary markets

5.1 The role of secondary markets

6 Conclusions

References

Figures 


\begin{abstract}
The recent financial crisis has highlighted the limits of the "originate to distribute" model of banking, but its nexus with the macroeconomy and monetary policy remains unexplored. I build a DSGE model with banks (along the lines of Holmström and Tirole [28] and Parlour and Plantin [39]) and examine its properties with and without active secondary markets for credit risk transfer. The possibility of transferring credit reduces the impact of liquidity shocks on bank balance sheets, but also reduces the bank incentive to monitor. As a result, secondary markets allow to release bank capital and exacerbate the effect of productivity and other macroeconomic shocks on output and inflation. By offering a possibility of capital recycling and by reducing bank monitoring, secondary credit markets in general equilibrium allow banks to take on more risk.
\end{abstract}

Keywords: credit risk transfer, dual moral hazard, monetary policy, liquidity, welfare.

JEL classification: E3, E5, G3 . 
The 2007-2009 crisis has shown that banking and financial structures can at times interact with macroeconomic conditions and policies (with monetary policy in particular) in ways that generate significant and even disruptive systemic instability. One major source of risk lies in a banking sector that relies heavily on credit risk transfer mechanisms, that weaken its commitment to monitor clients (as discussed, eg, by Rajan [41]).

Existing macro-models are not well equipped to capture these phenomena. Conversely, the banking and corporate finance literature has extensively analyzed the incentives and pricing mechanisms of credit risk transfer markets in a micro-framework, but has not explored the link with the macro-economy. Given the spreading of securitization in the last two decades and considering that the interplay between financial micro-structures and macro factors played a crucial role in the chain of events that led to the crisis, it seems important to include them explicitly in current models used for macro and monetary policy design.

The focus of this paper is twofold. First, it aims at creating a bridge between the macro ad the finance literature by embedding a micro-founded "Originate to Distribute" (OTD) model of banking into a standard macro framework. Second, it aims at analyzing the macroeconomic impact of financial market dis-functionalities, such as those stemming from the moral hazard problems associated with loan sales, particularly as those lead banks to take up too much risk.

The starting point is a standard DSGE model in the New Keynesian tradition. I introduce banks following Holmstrom and Tirole [28] and secondary markets as in Parlour and Plantin [39]. In the model I assume that banks are subject to liquidity shocks and may therefore wish to sell loan claims on unfinished projects in secondary markets. Both the origination and the selling activity are subject to moral hazard problems. Firms, after obtaining loans from the bank, might choose to exert low effort, hence undermining the success of a project if not monitored properly. By monitoring, banks acquire private information about firms' projects that cannot be passed on to other investors (banks are hence "informed investors"). This leads to a second moral hazard problem between depositors ("uninformed investors") and banks; this problem becomes more severe when the bank has the possibility of selling loans into secondary market. The model 
implies that the bank is inclined to offer the loan on the secondary market in the case of a liquidity shock or of it knows that the loan is non-performing. In presence of asymmetric information between sellers and buyers in the secondary market a pooling price emerges, that reduces the banks' incentive to monitor. In this context bank capital ratios are obtained as a solution to the third party contract that characterizes the abovementioned dual moral hazard problem. The possibility of capital recycling (loan sale on secondary markets) affects the incentive compatibility constraint of the bank.

The focus of the quantitative analysis is twofold. On the one side, we aim at exploring the transmission of various shocks (productivity, demand, monetary policy, asset price and liquidity shocks) into both, the model with and without secondary markets. Second, the efficiency of the credit risk transfer practice is tested by comparing the dynamic of investment and other macro variables in the models with and without secondary markets.

The main results are as follows. First, both with and without secondary markets, productivity and monetary policy shocks induce pro-cyclical bank capital ratios (capital ratios decline when output rises), while government expenditure shocks induce counter-cyclical bank capital ratios. An increase in productivity or an expansionary monetary policy, by raising asset prices, tend to reduce the severity of the moral hazard problem between banks and uninformed investors, as it is easier to meet the incentive compatibility constraints for both the bank and the entrepreneur. In this case, bank capital ratios, that act as a discipline device for the moral hazard problem, decrease. An increase in government spending, instead, by crowding out investment, implies a fall in asset price, which strengthens the moral hazard problems and requires higher capital ratios. Second, a comparison between the two models shows that the presence of secondary loan markets tends to amplify the dynamic of macro variables, particularly the financial ones. This is because secondary markets offer a possibility of capital recycling that reduces the incentives of the bank to monitor and allows them to take up more risk. Formally, the proceeds from the loan sale relax the incentive compatibility constraints, hence freeing up capital. As a large amount of liquidity is available to finance projects, the economy over-reacts to positive shocks: a form of exuberance arises in equilibrium. 


\section{Introduction}

The 2007-2009 crisis has shown that banking and financial structures can at times interact with macroeconomic conditions and policies (with monetary policy in particular) in ways that generate significant - even disruptive - systemic instability. In recent discussions two sources of risk have been identified: a prolonged expansionary monetary policy (see, eg, Taylor [45]) and a banking sector that relies heavily on credit risk transfer mechanisms, that weaken its commitment to monitor clients (as discussed, eg, by Rajan [41]). In the decade prior to the Great Turmoil both phenomena were in fact observed: central banks maintained exceptionally expansionary monetary conditions for several years, while securitization and credit risk-transfer techniques expanded at an unprecedented scale.

Existing macro-models are not well equipped to capture these phenomena. Members of the "financial accelerator" family (beginning with Bernanke, Gertler and Gilchrist [10], BGG hereafter) typically ignore bank intermediation and model the asymmetric information problem in borrowerlender relationships through a debt contract a' la Gale and Hellwig [24]. Even models that explicitly incorporate bank risk, such as Angeloni and Faia [3] or Gertler and Karadi [25] ${ }^{1}$, do not allow for the existence of secondary credit markets. Conversely, the banking and corporate finance literature has extensively analyzed the incentives and pricing mechanisms of credit risk transfer markets in a micro-framework (see next session for literature review), but has not explored the link between these elements and the macro-economy. Since the interplay between financial micro-structures and macro factors played a crucial role in the chain of events that led to the crisis, it seems important to include them explicitly in current models used for macro and monetary policy design. This can help us not only to think about macro-policies, but also to study prudential measures of a structural nature, that can make the financial system more resilient.

The focus of this paper is twofold. First, it aims at creating a bridge between the macro and the finance literature by embedding a micro-founded "Originate to Distribute" (OTD) model of banking into a standard macro framework. This will help to analyze the interplay between the monetary transmission mechanism and the market for credit risk transfer. Second, it aims at analyzing the macroeconomic impact of some of the dis-functionalities referred to above, particularly those

\footnotetext{
${ }^{1}$ See also Chen [14] and Meh and Moran [32].
} 
stemming from the moral hazard problems associated with loan sales. Such dis-functionalities might, indeed, have been responsible for inducing excessive risk taking behavior on the banking side and might have amplified aggregate risk.

The starting point is a standard DSGE model in the New Keynesian tradition. Maintaining the assumption of nominal rigidities allows us to study the monetary transmission mechanism. The micro-foundations for the OTD model of banking will consider both, the beneficial and adverse elements that characterize the activities of loan origination and of sale in secondary markets. In the model I assume that banks are subject to liquidity shocks and, because of this, they may wish to sell loan claims on unfinished projects in secondary markets. Liquidity shocks can originate from a variety of sources, including prudential capital constraints. Both the origination and the selling activity are subject to moral hazard problems ${ }^{2}$. Firms, after obtaining loans from the bank, might choose to exert low effort, hence undermining the success of a project if not monitored properly. By monitoring, banks acquire private information about firms' projects that cannot be passed on to other investors (banks are hence "informed investors"). This leads to a second moral hazard problem between depositors ("uninformed investors") and banks; this problem becomes more severe when the bank has the possibility of selling loans into secondary market. The bank is inclined to offer the loan on the secondary market in the case of a liquidity shock or of it knows that the loan is non performing. In presence of asymmetric information between sellers and buyers in the secondary credit market a pooling price emerges, that reduces the banks' incentive to monitor.

The focus of the quantitative analysis is twofold. On the one side, we aim at exploring the transmission of various shocks (productivity, demand, monetary policy, asset price and liquidity shocks) into both, the model with and without secondary markets. Second, the efficiency of the credit risk transfer practice is tested by comparing the dynamic of investment and other macro variables in the models with and without secondary markets.

The main results are as follows. First, both with and without secondary markets, productivity and monetary policy shocks induce pro-cyclical bank capital ratios (meaning that capital ratios decline when output rises), while government expenditure shocks induce counter-cyclical bank capital ratios. This is so since e.g. negative productivity and contractionary monetary policy

\footnotetext{
${ }^{2}$ For this micro-foundations I follow Parlour and Plantin [39], who introduce secondary markets for credit risk transfer in a model of banking a' la Holmström and Tirole [28]
} 
shocks tend to strengthen the moral hazard problem between banks and uninformed investors, hence they require higher market discipline in the form of higher capital ratios. The opposite is true for the fiscal shock. Second, a comparison between the two models shows that the presence of secondary loan markets tends to amplify the dynamic of macro variables, particularly the financial ones. This is because secondary markets offer a possibility of capital recycling that reduces the incentives of the bank to monitor and allows to take up more risk.

Section 2 provides an excursus of the finance literature on the pros and cons of the OTD model of banking. Section 3 describes the model. Section 4 shows the quantitative implications of the model in terms of transmission of shocks and monetary policy. Section 5 concludes.

\section{Micro-foundations from the Banking and Corporate Finance Literature}

The OTD model of banking spread quickly in the decade prior to the crisis, bringing several advantages, including better risk sharing possibilities for lenders and lower cost of capital and increased availability of funds for borrowers. However, over time several dis-functionalities emerged. As noted by Brunnermeier [11] and Ashcraft and Schuermann [5] some features of the credit risk transfer mechanism can impair market functioning in times of strain. Among them are incentive problems associated with trading in asset-backed securities, asymmetric information in secondary markets, increased level of complexity of the financial instruments involved and the related evaluation difficulties. Concerns about the progressive involvement of banks in credit risk transfer - loan sales and credit derivatives - were mentioned in recent years by several policy reports (ECB [21], BIS [7]) and academic papers (Minton et al. [33], Duffie [19]).

Figure 1 shows the trading values in U.S. secondary market loan sales. Two basic messages emerge. First, there was an unprecedented surge in trading volumes especially in the pre-crisis decade. Second, while the growth stopped at the onset of the financial turmoil, volume levels did not decline but merely levelled-off.

The surge resulted in benefits from higher diversification and liquidity. Moreover, there was also a significant expansion in trading of risk of un-rated borrowers, who typically need bank monitoring (FitchRatings [22]). Though this tendency was politically welcome in some countries, 
its merits from the viewpoint of the performance and stability of the financial system are more questionable. In the finance literature there have been two main strands studying credit risk transfers. On the one side, several papers focusing on optimal security designs generally highlighted the beneficial risk sharing and signaling properties of credit risk transfer. On the other side, the literature on corporate finance and banking, by analyzing the incentive problems associated with loan sales, stressed the risk, in terms of lower incentive to monitor, associated with the disruption of the relationship banking activity.

The literature on security design had studied the optimal portfolio allocation in a context in which bank can originate new securities and transfer credit risks. The basic ideas had been originally developed in papers studying the problem of optimal equity issuing under asymmetric information (see Leland and Pyle [31], Myers and Majluf [34], Allen and Gale [2]). A firm seeking funds to finance a project will need to place equities on the market, however the firm's informational advantage might discourage investors from buying the equity. In this context the fraction of equities retained by the firm in its own balance sheet might provide a signal to the market of the soundness of the investment project. Subsequent papers have generalized this idea to alternative types of securities (such as debt, ABS) or tranches thereof (see Duffie and De Marzo [18], Oldfield [36], De Marzo [17]). This literature had shown that the emergence of a signaling equilibrium in the market for credit risk transfer can improve risk sharing opportunities, free up capital (Chiesa [15], Cerasi and Rochet [13]) and mitigate the lemon's problem arising from the banks' informational advantage. Most of these models are static, partial equilibrium (no role has even been assigned to liquidity provided by central banks) and impose strong assumptions on the underlying shocks. The typical assumption is that idiosyncratic shocks to loans are uncorrelated among themselves and with macro factors (see also Krahnen and Franke 2007 [30]).

Another strand of the finance literature has focused on the incentive problems associated with loan sales. Pennacchi [37] and Gorton and Pennacchi [27] were the first to emphasize that transfer of loan risk to a third party might impair the incentives to monitor. Along this line several other authors have come to the conclusions that credit risk transfer might be welfare detrimental due to the possibility that the bank can exploit private information (see Duffee and Zhou [20], Behr and Lee [6], Morrison [35], Parlour and Plantin [39], Parlour and Winton [40]). Most of those papers 
build models with a dual moral hazard problem, between banks and investors on the one side and between banks and borrowers on the other side. In most cases such dual moral hazard follows the lines indicated in Holmström and Tirole [28]. Most of the analyses conclude that while markets for credit risk transfer improve risk-sharing increase liquidity, they can also result in more severe moral hazard problems between banks and uninformed investors. Empirical studies for the US have indeed shown that lending standards declined more in areas with high securitization (see Keys et al. [29], Dell'Ariccia, Igan and Laeven [16]). Whether the detrimental effects on moral hazard prevails on the beneficial effects on liquidity and risk sharing on welfare grounds is a question that cannot be answered without an explicit model.

\section{The Model}

The economy is populated by three type of agents: households, entrepreneurs and banks. The latter two are finitely lived: this assumption is needed to prevent that either of the two would be able to accumulate enough resources to overcome the liquidity constraints. Production includes three sectors: competitive firms producing in the final sectors which assemble intermediate goods, monopolistic competitive firms producing in the intermediate good sectors which face adjustment costs in changing prices a' la Rotemberg [42] and capital producers. The latter obtain funds from banks to finance investment projects of variable scale. Banks obtain funds either through deposits (in absence of secondary markets for credit risk transfer) or through demandable loans (in presence of secondary markets).

The financial contract, which follows Holmström and Tirole [28] is a three party contract subject to a dual moral hazard problem. On the one side, firms can influence the probability of success of the project which can be high, low or very low and obtain private benefits in the last two cases. To overcome such moral hazard problem two things are needed: banks' monitoring activity and entrepreneurial stakes (in the form of net worth) into the project. On the other side, banks' monitoring activity is also costly. Such costs are at the origin of a second moral hazard problem which arises between depositors (or uninformed investors) and banks. The incentives to discipline this second moral hazard problem are given by the amount of bank capital involved in the project. Everything else equal, investors and depositors give more funds to well capitalized banks. 
The treatment of the secondary market for credit risk transfer follows Parlour and Plantin [39]. I assume that banks are subject to liquidity shocks. In absence of secondary market such shocks induce banks to discount the proceeds from the investment activity. In presence of secondary markets, banks can sell loans, and they will do so in two circumstances (or both): if they receive a liquidity shock, and if they hold non-performing loans. Uninformed investors are unable to distinguish among those two cases, hence in equilibrium a pooling price clears the market. In equilibrium this reduces the banks incentives to monitor and reinforces the moral hazard problem between banks and uninformed investors. Depending on the relative size of various parameters such as the probability of non-performing loans, the size of the liquidity shock and the size of the monitoring costs, it is possible to establish whether the presence of secondary market increases or depresses aggregate investment.

Finally, the short term interest rate is assumed to be pegged by a central bank through a Taylor-type rule.

\section{Households}

A continuum of households consume, work and invest in bank deposits and capital. Furthermore they are the owner of the monopolistic competitive sector. They take consumption decisions to maximize the following lifetime expected utility:

$$
E_{0} \sum_{t=0}^{\infty} \beta^{t}\left\{U\left(C_{t}\right)-V\left(H_{t}\right)\right\}
$$

where $C_{t}$ denotes households consumption and $H_{t}$ labour hours. Their budget constraint, in real terms, reads as follows:

$$
C_{t}+q_{t} I_{t}^{h}+D_{t+1}=\left(1+r_{t}^{n}\right) D_{t}+r_{t}^{k} K_{t}^{h}+\frac{W_{t}}{P_{t}} H_{t}+\Theta_{t}-\tau_{t}
$$

where $q_{t}$ denotes the price of capital, $I_{t}^{h}$ denotes denotes capital investment done by households, $\left(1+r_{t}^{n}\right)$ is the gross nominal interest rate received on deposits, $D_{t}$ are real deposits, $r_{t}^{k}$ is the rental rate of capital, $K_{t}^{h}$ is the amount of capital invested by households, $\frac{W_{t}}{P_{t}} H_{t}$ is real labour income, $\Theta_{t}$ are the profits that they receive from the monopolistic competitive sector and $\tau_{t}$ are lump sum taxes. 
The capital investment evolves according to:

$$
K_{t+1}^{h}=(1-\delta) K_{t}^{h}+I_{t}^{h}
$$

The first order conditions of the above problem read as follows:

$$
\begin{gathered}
u^{\prime}\left(C_{t}\right)=\beta E_{t}\left\{u^{\prime}\left(C_{t+1}\right) \frac{\left(1+r_{t}^{n}\right) P_{t}}{P_{t+1}}\right\} \\
q_{t} u^{\prime}\left(C_{t}\right)=\beta E_{t}\left\{u^{\prime}\left(C_{t+1}\right)\left(q_{t+1}(1-\delta)+r_{t+1}^{k}\right)\right\} \\
\frac{W_{t}}{P_{t}} u^{\prime}\left(C_{t}\right)=-v^{\prime}\left(H_{t}\right)
\end{gathered}
$$

Equation 4 is the standard Euler conditions with respect to deposits. Equation 5 is the first order condition with respect to capital holding. Finally, equation 6 is the first order condition with respect to labour hours. The set of first order conditions must hold alongside with a no-Ponzi condition on wealth.

\subsection{Final good firms}

Different varieties are assembled by final good firms through a standard Dixit- Stiglitz aggregator, $Y_{t} \equiv \int_{0}^{1}\left[\left(Y_{t}^{i}\right)^{\frac{\epsilon-1}{\epsilon}} d i\right]^{\frac{\epsilon}{\epsilon-1}}$. The optimal allocation of expenditure on each variety is given by $Y_{t}^{i}=$ $\left(\frac{P_{t}^{i}}{P_{t}}\right)^{-\varepsilon} Y_{t}$, where $P_{t} \equiv \int_{0}^{1}\left[\left(P_{t}^{i}\right)^{\frac{\epsilon-1}{\epsilon}} d i\right]^{\frac{\epsilon}{\epsilon-1}}$ is the aggregate price index.

\subsection{Monopolistic competitive firms}

Each firm produces the single variety $i$ and has monopolistic power in the production of its own variety and therefore has leverage in setting the price. In changing prices it faces a quadratic cost equal to $\frac{\vartheta}{2}\left(\frac{P_{t}^{i}}{P_{t-1}^{i}}-1\right)^{2}$, where the parameter $\vartheta$ measures the degree of nominal price rigidity. The higher $\vartheta$ the more sluggish is the adjustment of nominal prices. In the particular case of $\vartheta=0$, prices are flexible. Each firm rents finished capital and assembles it with labour (supplied by the workers) to operate a constant return to scale production function for the variety $i$ of the intermediate good:

$$
Y_{t}^{i}=A_{t}\left(H_{t}^{i}\right)^{\alpha}\left(K_{t}^{i}\right)^{1-\alpha}
$$


where $A_{t}$ is an aggregate productivity shock which follows an $\operatorname{AR}(1)$ process and $K_{t}^{i}$ denotes rental capital. Each monopolistic firm chooses a sequence $\left\{K_{t}^{i}, H_{t}^{i}, P_{t}^{i}\right\}$, taking nominal wages $W_{t}$ and the rental rate of capital $r_{t}^{k}$, as given, in order to maximize expected discounted nominal profits:

$$
E_{0}\left\{\sum_{t=0}^{\infty} \Lambda_{0, t}\left[P_{t}^{i} Y_{t}^{i}-\left(W_{t} H_{t}^{i}+P_{t} r_{t}^{k} K_{t}^{i}\right)-\frac{\vartheta}{2}\left[\frac{P_{t}^{i}}{P_{t-1}^{i}}-1\right]^{2} P_{t}\right]\right\}
$$

subject to the constraint $A_{t}\left(H_{t}^{i}\right)^{\alpha}\left(K_{t}^{i}\right)^{1-\alpha} \leq Y_{t}^{i}$, where $\Lambda_{0, t}$ is the households' stochastic discount factor.

Let's denote by $\left\{m c_{t}\right\}_{t=0}^{\infty}$ the sequence of Lagrange multipliers on the above demand constraint, and by $\tilde{p}_{t} \equiv \frac{P_{t}^{i}}{P_{t}}$ the relative price of variety $i$. As all firms are symmetric, we can drop the index $i$. The first order conditions of the above problem read as follows:

$$
\begin{gathered}
\frac{W_{t}}{P_{t}}=m c_{t} A_{t} \alpha\left(H_{t}\right)^{\alpha-1}\left(K_{t}\right)^{1-\alpha} \\
r_{t}^{k}=m c_{t} A_{t}\left(H_{t}\right)^{\alpha}(1-\alpha)\left(K_{t}\right)^{-\alpha} \\
0=U_{c, t} Y_{t} \tilde{p}_{t}^{-\varepsilon}\left((1-\varepsilon)+\varepsilon m c_{t}-U_{c, t} \vartheta\left[\pi_{t} \frac{\tilde{p}_{t}}{\tilde{p}_{t-1}}-1\right] \frac{\pi_{t}}{\tilde{p}_{t-1}}+\right. \\
+\vartheta E_{t}\left[U_{c, t+1} \pi_{t+1} \frac{p_{t+1}}{p_{t}}-1\right] \pi_{t+1} \frac{\tilde{p}_{t+1}}{\tilde{p}_{t}^{2}}
\end{gathered}
$$

where $\pi_{t}=\frac{P_{t}}{P_{t-1}}$ is the gross aggregate inflation rate. Notice that all firms employ an identical capital/labour ratio in equilibrium, so individual prices are all equal in equilibrium. The Lagrange multiplier $m c_{t}$ plays the role of the real marginal cost of production. In a symmetric equilibrium $\tilde{p}_{t}=1$. This allows to rewrite equation 11 in the following form:

$$
\begin{aligned}
U_{c, t}\left(\pi_{t}-1\right) \pi_{t}= & \beta E_{t}\left\{U_{c, t+1}\left(\pi_{t+1}-1\right) \pi_{t+1}\right\}+ \\
& +U_{c, t} A_{t}\left(H_{t}\right)^{\alpha}\left(K_{t}\right)^{1-\alpha} \frac{\varepsilon}{\vartheta}\left(m c_{t}-\frac{\varepsilon-1}{\varepsilon}\right)
\end{aligned}
$$

The above equation is a non-linear forward looking New-Keynesian Phillips curve, in which deviations of the real marginal cost from its desired steady state value are the driving force of 
inflation. ${ }^{3}$

\subsection{Capital good production}

Following Holmström and Tirole [28] we assume that a continuum of entrepreneurs has access to the same technology for producing capital goods, although their returns are subject to idiosyncratic risks, $R^{j}$. Due to the linear specification of the production function of capital goods, of the private benefits accruing to the entrepreneur and of the monitoring technology, we can specify ex-ante the optimization problems involving entrepreneurs and banks by referring directly to the aggregate variables. Hence we drop the index $j$ at this stage.

Projects have a variable scale $I_{t}$ and are financed partly with entrepreneurial net worth, $N W_{t}$, and partly with bank loans, $L_{t}$. Although all projects produce the same publicly visible returns, they have different probability of success. The latter is determined by the entrepreneurs. In absence of proper incentives or outside monitoring, entrepreneurs might "shirk", i.e. reduce the probability of success of the project in order to enjoy a private benefit. The moral hazard problem is formalized by assuming that entrepreneurs can choose among three different project outcomes. The first project, labeled as "good project", has a high probability of success $p_{h}$ and zero private benefits. The second project, labeled as "bad project", is associated with an entrepreneur who shirks: it has a lower probability of success, $p_{l}<p_{h}$, and provides private benefits $b$. Finally, the third project still delivers a probability of success $p_{l}$ but allows for private benefits $B>b$. Private benefits are assumed to be proportional to the value of investment, $q_{t} I_{t}$. It is assumed that there are two levels of shirking with the same probability of success in order to allow for a rich characterization of monitoring, alongside with the entrepreneurs preferring the high benefit project.

\subsection{Banks}

Banks have access to a monitoring technology which takes different forms: inspection of firms' balance sheet position and potential cash flow, management quality, verification that the firm conforms with financial covenants, etc.. It is assumed that monitoring can prevent the shirking project with benefits $B$, but not the one with benefits $b$. This reduces the incentive to shirk, but

\footnotetext{
${ }^{3}$ Woodford [46].
} 
not fully, so as to retain some role for entrepreneurial net worth as a discipline device.

Bank monitoring is privately costly and such cost, $c$, is proportional to the project scale, $I_{t}$. This creates a second moral hazard problem between the bank, on the one side, and uniformed investors (depositors or traders in secondary markets), on the other. The mis-incentives to reduce the amount of monitoring ( a form of bank shirking) become particularly severe when the bank can transfer risks in secondary markets. Such moral hazard problem is disciplined by the amount of bank capital invested in the project, $B K_{t}$. Once the cost of monitoring have been paid, the bank is able to lend an amount $L_{t}=B K_{t}+D_{t}-c I_{t}$.

The contract takes place over three periods. Hence we assume that each period $t$ is divided in three sub-period, 0,1 and 2. At time 0 the lending and deposit contracts are written and the behavior of the firm and the bank (shirk versus no shirk) are decided. At time 1 the monitoring bank privately learns about the quality of its own project and of the possible occurrence of a liquidity shock, and may engage in a risk-transfer transaction. At period 2 the outcome of the project becomes common knowledge and all payoffs are made.

To model the bank appetite for liquidity I follow Parlour and Plantin [39] and assume that the bank has a stochastic discount factor. The discount factor becomes indeed higher in presence of liquidity shocks. The bank obtains liquidity from the interbank market. Suppose that at time 1 there is an unexpected increase in counter-party risk, hence the precautionary demand for liquidity by the bank increases ${ }^{4}$. Unless the central bank fully and immediately accommodates the increased liquidity demand, the discount factor for each bank will increase. Such shortage of liquidity occurs with probability $\zeta$. Hence, the stochastic discount factor can be modeled as follows: $\theta_{t}=\theta \in(0,1)$ with probability $\zeta$ and to 1 with probability $(1-\zeta)$.Such formulation captures unanticipated changes in the opportunity cost of carrying out outstanding loans. In absence of secondary market for credit risk transfer, the bank is unable to liquidate its investment, hence the return for the bank of investing in the portfolio of project $I_{t}$ in this case will be discounted by the average factor $\bar{\theta}=\zeta \theta+(1-\zeta)$. On the other side, in presence of secondary market banks can sell loans in case of a liquidity shock and enjoy a unitary discount factor.

Project are assumed to be perfectly correlated. Such assumption is useful from a technical

\footnotetext{
${ }^{4}$ Abrupt and large increases in liquidity hoarding by banks has been observed in the most acute phases of the financial crisis after September 2008 both, in the US and in Europe.
} 
point of view, as it makes irrelevant the exact distribution of assets among all parties. Moreover such an assumption is particularly apt in modeling the returns of asset backed securities. Indeed, it has been recently argued (see Adrian and Brunnermeier [1]) that failures in pricing correctly asset backed securities and/or credit derivatives were related to the assumption, made in value at risk pricing techniques, of lack of correlation among the underlying assets. Such correlation can indeed increase the amplification of systemic risk, as opposed to individual bank risk.

\subsection{The Financial Contract in Absence of Secondary Markets}

In absence of secondary market for credit risk transfer, the bank provides finance to entrepreneurs by employing funds from depositors and its own net worth. It is possible to restrict attention to one-period contract due to the anonymity assumption ${ }^{5}$. There is three party contract between depositors, banks and entrepreneurs which delivers a return of zero if the project fails and a gross return, $R_{t}$, if the project succeeds. Total project return is linearly divided between depositors, $R_{t}^{h}$,banks, $R_{t}^{b}$, and entrepreneurs, $R_{t}^{e}$ :

$$
R_{t}^{j}=R_{t}^{h}+R_{t}^{b}+R^{e}
$$

Limited liability ensures that no agent earns a negative return. Since the bank monitors firms, it is assumed ex-ante that project succeed with probability $p_{h, t}$. This rules out the project with benefit $B$. The firm is then left to choose between the project with benefit $b$ and the one with zero benefit. It is assumed that entrepreneurs have the bargaining power so that the financial contract is designed to maximize their expected return given the participation constraint for uninformed investors and banks and the incentive compatibility constraints for banks and entrepreneurs. The optimization plan determines the investment scale, $I_{t}$, banks' capital, $B K_{t}$, funds from uninformed investors, $D_{t}$, alongside with returns, $R_{t}^{h}, R_{t}^{b}, R^{e}$ and takes the following form:

$$
\operatorname{Max}_{\left\{I_{t}, B K_{t}, D_{t}, R_{t}^{h}, R_{t}^{b}, R^{e}\right\}} q_{t} p_{h} R^{e} I_{t}
$$

subject to:

$$
\begin{aligned}
& p_{h} R^{e} q_{t} I_{t} \geq p_{l} R^{e} q_{t} I_{t}+q_{t} I_{t} b \\
& \bar{\theta} p_{h} R_{t}^{b} q_{t} I_{t}-c I_{t} \geq \bar{\theta} p_{l} R_{t}^{b} q_{t} I_{t}
\end{aligned}
$$

\footnotetext{
${ }^{5}$ See Bernanke, Gertler and Gilchrist [10] and Carlstrom and Fuerst [12].
} 


$$
\begin{gathered}
\bar{\theta} p_{h} R_{t}^{b} q_{t} I_{t} \geq\left(1+r_{t}^{m}\right) B K_{t} \\
p_{h} R_{t}^{h} q_{t} I_{t} \geq\left(1+r_{t}^{n}\right) D_{t} \\
I_{t} \leq N W_{t}+B K_{t}+D_{t}-c I_{t} \\
R_{t}=R_{t}^{h}+R_{t}^{b}+R^{e}
\end{gathered}
$$

Constraint 15 is the incentive compatibility constraint for the entrepreneur; it states that the returns from pursuing the zero benefit project should be higher that the expected returns from pursuing the project returning a private benefit $b$. Equation 16 is the incentive compatibility constraint of the bank; it states that the expected returns from monitoring should be higher than the expected returns from non-monitoring. The time $t$ value of the expected payout depends on the average realization of the stochastic discount factor, $\bar{\theta}$. Equation 17 and 18 are the participation constraints for the bank and the uninformed investors ${ }^{6}$ as they state that expected returns form this contract should at least cover market driven returns. The average stochastic discount factor also affects banks' returns entering participation constraint. Finally, equation 19 states that loanable funds must cover the financing needs, while equation 20 shows the linear allocation of the project returns.

The return structure is determined by knowing that in equilibrium the incentive compatibility constraints, 15 and 16, must holds with equality. This delivers:

$$
\begin{gathered}
R^{e}=\frac{b}{p_{h}-p_{l}} \\
R_{t}^{b}=\frac{c}{\bar{\theta} q_{t}\left(p_{h}-p_{l}\right)}
\end{gathered}
$$

Using 20 it is possible to obtain the return for depositors:

$$
R_{t}^{h}=R_{t}-\frac{b}{p_{h}-p_{l}}-\frac{c}{\bar{\theta} q_{t}\left(p_{h}-p_{l}\right)}
$$

Notice that the severity of the moral hazard problems, as represented by the private benefits $b$ and the cost of monitoring $c$, optimally determines the share of returns allocated to entrepreneurs

\footnotetext{
${ }^{6}$ Since households are risk averse, they discount all their expcted returns by the stochastic discount factor $\Lambda_{t, t+1}=$ $E_{t}\left\{\frac{u_{c, t+1}}{u_{c, t}}\right\}$. Since such a stochastic discount factor applies to both sides of the participation constraint (equation 18), it can be canceled out.
} 
and banks. The higher the benefits from shirking, the tighter the moral hazard problem and the higher the returns that banks and entrepreneurs can extract. To assess the role of the liquidity shock, it suffices to notice that the lower the expected value of the stochastic discount factor (the further $\bar{\theta}$ is to unity), the lower the return accruing to the banker. After merging the equation for the optimal return to depositors, 23 , together with depositors' participation constraint, 18, and with equation 19, we obtain the optimal scale of the project:

$$
I_{t}=\frac{N W_{t}+B K_{t}}{1+c-\frac{q_{t} p_{h}}{1+r_{t}^{n}}\left(R_{t}-\frac{b}{p_{h}-p_{l}}-\frac{c}{\bar{\theta} q_{t}\left(p_{h}-p_{l}\right)}\right)}
$$

The scale of the project is larger the larger the stakes of the entrepreneur and the bank into the project. On the other side, an increase in the cost of monitoring and in the private benefits for the entrepreneurs, reduce the scale of investment, as the moral hazard problems become more severe. An increase in the price of capital, $q_{t}$, increases the scale of investment. This is so since asset prices booms increase the value of available funds for investment. Finally, an increase in the nominal interest rate, $r_{t}^{n}$, reduces the scale of investment; contractionary monetary policy, by reducing available liquidity, also reduces investment. The participation constraint to the bank determines the market driven rate to bankers:

$$
\left(1+r_{t}^{m}\right)=\frac{\bar{\theta} q_{t} p_{h} R_{t}^{b} I_{t}}{B K_{t}}
$$

The return $r_{t}^{m}$ is defined as the market driven return of bank capital. It serves the purpose of defining the reservation value for the bank. Hence it includes returns from various possible alternative use of bank capital, which could be exogenously given, provided that they satisfy the participation constraint 25. Similarly to the return on deposit, also the return $r_{t}^{m}$ should be equalized by arbitrage to the return on capital, $\frac{\left(q_{t+1}(1-\delta)+r_{t+1}^{k}\right)}{q_{t}}$, as this is one alternative use for bank capital. After substituting the equation for the optimal return accruing to the banker, 22, into equation 25 , it is possible to obtain the optimal amount of bank capital:

$$
B K_{t}=\frac{p_{h} c I_{t}}{\left(p_{h}-p_{l}\right)\left(1+r_{t}^{m}\right)}
$$

Higher monitoring costs induce more severe moral hazard problems, hence they require higher stake of bank capital into the project as discipline device. Also the higher is the market return, 
the lower is the amount of capital that the banker is willing to invest in the project, since it looses other profitable opportunities.

Finally, the optimal amount of deposits is determined using the participation constraint to depositors, 18, combined with the optimal return on deposits, 23 :

$$
D_{t}=\frac{q_{t} p_{h} I_{t}\left(R_{t}-\frac{b}{p_{h}-p_{l}}-\frac{c}{\bar{\theta} q_{t}\left(p_{h}-p_{l}\right)}\right)}{\left(1+r_{t}^{n}\right)}
$$

Equation 27 shows that the higher is the return accruing to the depositors, the higher is the optimal amount of deposits. On the other side, the higher is the market return, the lower is the optimal amount of deposits, as the opportunity cost is higher.

The bank capital ratio is defined as:

$$
C A R_{t}=\frac{B K_{t}}{B K_{t}+D_{t}}
$$

\subsection{The Financial Contract with Secondary Market for Credit Risk Transfer}

In presence of a market for credit risk transfer the bank has the possibility to sell a claim on loans' cash flows. In this respect there are possible gains from trade between the bank and outside investors. The bank might want to sell such claims either because it has received a liquidity shock or because it recognized the project as a bad one. A secondary market is illiquid if banks sells only in the second case, while it is liquid when a pooling equilibrium arises. If the market is liquid, investors know that the bank will sell either because it has received a liquidity shock, with probability $\zeta p_{h}$, or because it has non performing loans, with probability $p_{l}$. The pooling price in the secondary market will be determined as follows:

$$
r=\frac{\zeta p_{h}}{1-p_{h}+\zeta p_{h}}
$$

Notice that $r<p_{h}$. If the probability of a liquidity shock, $\zeta$, is zero the price for the claim is also zero; investors know for sure that the bank will sell only bad loans. On the other side, when $\zeta=1$ the price of the claim approaches the unconditional probability of success $p_{h}$. 
The three party contract in the case in which the bank can sell claims on the secondary market takes the following form (the index $s$ stands for secondary market):

$$
\operatorname{Max}_{\left\{I_{t}^{s}, B K_{t}^{s}, D_{t}^{s}, R_{t}^{h, s}, R_{t}^{b, s}, R^{e, s}\right\}} q_{t} p_{h} R^{e, s} I_{t}^{s}
$$

subject to:

$$
\begin{gathered}
p_{h} R^{e, s} q_{t} I_{t} \geq p_{l} R^{e, s} q_{t} I_{t}+b q_{t} I_{t} \\
p_{h} R_{t}^{b, s} q_{t} I_{t} \geq c I_{t}+r R_{t}^{b, s} q_{t} I_{t} \\
q_{t} p_{h} R_{t}^{b, s} I_{t}^{s} \geq\left(1+r_{t}^{m}\right) B K_{t}^{s} \\
p_{h} R_{t}^{h, s} q_{t} I_{t}^{s} \geq\left(1+r_{t}^{n}\right) D_{t}^{s} \\
I_{t}^{s} \leq N W_{t}^{s}+B K_{t}^{s}+D_{t}^{s}-c I_{t}^{s} \\
R_{t}^{s}=R_{t}^{h, s}+R_{t}^{b, s}+R^{e, s}
\end{gathered}
$$

The presence of a secondary market has an impact on both the incentive compatibility and the participation constraint of the bank, equations 31 and 32. Since banks can sell loans in presence of a liquidity shock, the average discount factor $\bar{\theta}$ is not relevant any longer. Let's now examine more closely how the bank' incentive compatibility constraint, equation 31, changes. The payoffs to the bank that monitors is: $p_{h} R_{t}^{b, s} q_{t} I_{t}^{s}$. Indeed, with probability $1-p_{h}+\zeta p_{h}$ the bank sells its claim on the secondary market at a price $r=\frac{\zeta p_{h}}{1-p_{h}+\zeta p_{h}}$. With probability $p_{h}(1-\zeta)$ it does not sell the claim and discounts the payoffs at a rate of 1 . Hence the expected value of the investment is: $p_{h} R_{t}^{b, s} q_{t} I_{t}^{s}$. If the bank shirks, the right end side of equation 31, the bank can sell its promised payment, $q_{t} R_{t}^{b, s} I_{t}^{s}$, at a price $r$.

After solving for the new incentive compatibility constraints we find the optimal returns for this case:

$$
\begin{gathered}
R^{e, s}=\frac{b}{p_{h}-p_{l}} \\
R_{t}^{b, s}=\frac{c}{q_{t}\left(p_{h}-r\right)} \\
R_{t}^{h, s}=R_{t}-\frac{b}{p_{h}-p_{l}}-\frac{c}{q_{t}\left(p_{h}-r\right)}
\end{gathered}
$$


Following the calculations shown in the previous section we can also recover the optimal investment scale, deposits and bank capital which are:

$$
\begin{gathered}
I_{t}^{s}=\frac{N W_{t}^{s}+B K_{t}^{s}}{1+c-\frac{q_{t} p_{h}}{1+r_{t}^{n}}\left(R_{t}^{s}-\frac{b}{p_{h}-p_{l}}-\frac{c}{q_{t}\left(p_{h}-r\right)}\right)} \\
B K_{t}^{s}=\frac{p_{h} c I_{t}^{s}}{\left(p_{h}-r\right)\left(1+r_{t}^{m}\right)} \\
D_{t}^{s}=\frac{q_{t} p_{h} I_{t}^{s}\left(R_{t}-\frac{b}{p_{h}-p_{l}}-\frac{c}{q_{t}\left(p_{h}-r\right)}\right)}{\left(1+r_{t}^{n}\right)}
\end{gathered}
$$

Notice that the main difference between the case with and the case without secondary markets arises in the term that represents the rents accruing to the bank, $\frac{c}{q_{t}\left(p_{h}-r\right)}$.

\subsection{Households Budget Constraint with Secondary Markets}

In presence of secondary markets uninformed investors have an additional investment opportunity, which consists in buying claims on loans cash flows. For this reason the households budget constraint needs to be emended accordingly. Let's define such claims as one period discounted (real) bonds, which are acquired at a price $r$, and pay a nominal amount $B_{t}=p_{h} q_{t} R_{t}^{b, s} I_{t}^{s}$ one period later. The new budget constraint read as follows:

$$
C_{t}+q_{t} I_{t}^{h}+D_{t+1}+r B_{t+1}=\left(1+r_{t}^{n}\right) D_{t}+B_{t}+r_{t}^{k} K_{t}^{h}+\frac{W_{t}}{P_{t}} H_{t}+\Theta_{t}-\tau_{t}
$$

The first order condition with respect to those claims is given by:

$$
r=\beta E_{t}\left\{\frac{u\left(C_{t+1}\right)}{u\left(C_{t}\right)}\right\}
$$

Hence in the general equilibrium the actual price of such claims should equate the stochastic discount factor.

\subsection{Consumption and Asset Accumulation for Bankers and Entrepreneurs}

We assume that both bankers and entrepreneurs are finitely lived. This prevents accumulation of savings up to the point that overcomes limited liability. We define $\gamma^{e}$ and $\gamma^{b}$ as the survival probabilities respectively for entrepreneurs and bankers. In terms of consumption decisions both agents 
consume all available resources at the end of their life. This implies that aggregate consumptions for entrepreneurs, $C_{t}^{e}$, and bankers, $C_{t}^{b}$, read as follows:

$$
\begin{aligned}
& C_{t}^{e}=\left(1-\gamma^{e}\right) q_{t} p_{h} R^{e} I_{t} \\
& C_{t}^{b}=\left(1-\gamma^{b}\right) q_{t} p_{h} R_{t}^{b} I_{t}
\end{aligned}
$$

After the contract returns are realized, surviving entrepreneurs and bankers receive the proceeds from the contract in the form of capital goods, so that $K_{t}^{e}=p_{h} R^{e} I_{t}$ and $K_{t}^{b}=p_{h} R^{b} I_{t}$. Such capital goods are then rent to producing firms or sold in the market. Hence the wealth, that surviving entrepreneurs and bankers carry over to the next period, is given by the returns from renting and selling capital goods, multiplied by the end of period capital:

$$
\begin{aligned}
& N W_{t+1}=\gamma^{e}\left[r_{t+1}^{k}+q_{t+1}(1-\delta)\right] p_{h} R^{e} I_{t} \\
& B K_{t+1}=\gamma^{b}\left[r_{t+1}^{k}+q_{t+1}(1-\delta)\right] p_{h} R_{t}^{b} I_{t}
\end{aligned}
$$

After substituting for the optimal scale of investment from equation 24, the net worth and bank capital accumulations read as follows:

$$
\begin{aligned}
& N W_{t+1}=\gamma^{e}\left[r_{t+1}^{k}+q_{t+1}(1-\delta)\right] p_{h} R^{e}\left(\frac{N W_{t}+B K_{t}}{\Gamma_{t}}\right) \\
& B K_{t+1}=\gamma^{b}\left[r_{t+1}^{k}+q_{t+1}(1-\delta)\right] p_{h} R_{t}^{b}\left(\frac{N W_{t}+B K_{t}}{\Gamma_{t}}\right)
\end{aligned}
$$

where $\Gamma_{t}=\left[1+c-\frac{q_{t} p_{h}}{1+r_{t}^{n}}\left(R_{t}-\frac{b}{p_{h}-p_{l}}-\frac{c}{\bar{\theta} q_{t}\left(p_{h}-p_{l}\right)}\right)\right]$. In presence of secondary markets, net worth and bank capital evolution read as follows:

$$
\begin{aligned}
& N W_{t+1}^{s}=\gamma^{e}\left[r_{t+1}^{k}+q_{t+1}(1-\delta)\right] p_{h} R^{e, s}\left(\frac{N W_{t}^{s}+B K_{t}^{s}}{\Gamma_{t}}\right) \\
& B K_{t+1}^{s}=\gamma^{b}\left[r_{t+1}^{k}+q_{t+1}(1-\delta)\right] p_{h} R_{t}^{b, s}\left(\frac{N W_{t}^{s}+B K_{t}^{s}}{\Gamma_{t}^{s}}\right)
\end{aligned}
$$

where $\Gamma_{t}^{s}=\left[1+c-\frac{q_{t} p_{h}}{1+r_{t}^{n}}\left(R_{t}^{s}-\frac{b}{p_{h}-p_{l}}-\frac{c}{q_{t}\left(p_{h}-r\right)}\right)\right]$. 


\subsection{Aggregation}

Aggregate capital, $K_{t}=K_{t}^{h}+K_{t}^{e}+K_{t}^{b}$, evolves according to the following law of motion:

$$
K_{t+1}=(1-\delta) K_{t}+p_{h} R I_{t}
$$

The resource constraint in this economy is given by:

$$
Y_{t}=C_{t}+C_{t}^{e}+C_{t}^{b}+I_{t}+G_{t}+\frac{\vartheta}{2}\left(\pi_{t}-1\right)^{2}+c I_{t}
$$

where $G_{t}$ is an exogenous government expenditure shocks. Since government expenditure is financed through lump sum taxation, it is not necessary to include the government budget constraint as fiscal policy plays a passive role.

\subsection{Monetary Policy}

We assume that monetary policy is conducted by means of an interest rate reaction function of this form:

$$
\ln \left(\frac{1+r_{t}^{n}}{1+r^{n}}\right)=\left(1-\phi_{r}\right)\left[\phi_{\pi} \ln \left(\frac{\pi_{t}}{\pi}\right)+\phi_{y} \ln \left(\frac{Y_{t}}{Y}\right)\right]+\phi_{r} \ln \left(\frac{1+r_{t-1}^{n}}{1+r^{n}}\right)+m_{t}
$$

where $m_{t}$ is a monetary policy shock which follows an AR (1) process. All variables are deviations from the target or steady state (symbols without time subscript). The steady state value of (net) inflation is set to zero. The weight $\phi_{\pi}$ on inflation is set above 1.5 to guarantee determinacy of the equilibrium, the weight $\phi_{y}$ is set to $0.5 / 4$. Finally the weight $\phi_{r}$ is varied in the simulations from 0 to 0.8 .

\subsection{Competitive Equilibrium}

Definition 1. Competitive equilibrium without secondary markets. A competitive equilibrium is an allocation

$$
\left\{C_{t}, C_{t}^{e}, C_{t}^{b}, I_{t}, Y_{t}, m c_{t}, \pi_{t}, H_{t}, K_{t+1}, R_{t}^{b}, R_{t}^{h}, D_{t}, N W_{t+1}, B K_{t+1},\left(1+r_{t}^{n}\right),\left(1+r_{t}^{m}\right),\left(1+r_{t}^{k}\right), q_{t}, \frac{W_{t}}{P_{t}}\right\}_{t=0}^{\infty}
$$

that satisfies equations $4,5,6,9,10,7,12,22,23,24,25,25,26,44,45,46,47,52,53$,

54 .

Definition 2. Competitive equilibrium with secondary markets. A competitive equilibrium is an allocation 


$$
\left\{C_{t}, C_{t}^{e}, C_{t}^{b}, I_{t}, Y_{t}, m c_{t}, H_{t}, K_{t+1}, R_{t}^{s, b}, R_{t}^{s, h}, D_{t}^{s}, N W_{t+1}^{s}, B K_{t+1}^{s},\left(1+r_{t}^{n}\right),\left(1+r_{t}^{m}\right),\left(1+r_{t}^{k}\right), q_{t}, \frac{W_{t}}{P_{t}}\right\}_{t=0}^{\infty}
$$

that satisfies equations $4,5,6,9,10,7,12,36,37,38,39,40,41,44,45,46,47,52,53,54$.

\subsection{The Role of Secondary Market and the Leverage Ratios}

Before turning to the quantitative implications of this model it is instructive to asses the interaction between secondary markets and the business cycle through some comparative static analyis on the behavior of the leverage ratios and the risk premia. The leverage ratio in absence of secondary market is given by:

$$
\frac{1}{\Gamma_{t}}=\frac{1}{1+c-\frac{q_{t} p_{h}}{1+r_{t}^{n}}\left(R_{t}-\frac{b}{p_{h}-p_{l}}-\frac{c}{\bar{\theta} q_{t}\left(p_{h}-p_{l}\right)}\right)}
$$

while in presence of secondary market the leverage ratio is given by:

$$
\frac{1}{\Gamma_{t}^{s}}=\frac{1}{1+c-\frac{q_{t} p_{h}}{1+r_{t}^{n}}\left(R_{t}^{s}-\frac{b}{p_{h}-p_{l}}-\frac{c}{q_{t}\left(p_{h}-r\right)}\right)}
$$

Lemma. The leverage ratio under secondary market is larger than the one in absence of them, namely shocks transmission is amplified, when the following condition occurs:

$$
\frac{c}{\bar{\theta} q_{t}\left(p_{h}-p_{l}\right)}>\frac{c}{q_{t}\left(p_{h}-r\right)}
$$

After substituting the average discount factor and the pooling price, the above condition can be re-stated as follows:

$$
\frac{c}{(\zeta \theta+(1-\zeta)) q_{t}\left(p_{h}-p_{l}\right)}>\frac{c}{q_{t}\left(p_{h}-\frac{\zeta p_{h}}{1-p_{h}+\zeta p_{h}}\right)}
$$

By holding constant firms' net worth and banks' capital, comparative static analysis shows that the leverage ratio, hence shock amplification, is higher under secondary markets when:

- When $p_{l}>\frac{r-(1-\bar{\theta}) p_{h}}{\bar{\theta}}$. When the probability that the project does not succeed is large enough, the moral hazard problem becomes more severe and the incentive for the bank to sell on secondary markets increase. In this case, shock transmission is amplified. Since more liquidity is available, under positive shocks, the economy can exploit better the investment opportunities: 
this amplifies expansionary shocks. On the other side, as banks are now doing more capital recycling, negative shocks are exacerbated by the depressed returns to investment.

- When $\theta<\frac{\left(p_{h}-r\right)}{\zeta\left(\left(p_{h}-p_{l}\right)\right.}-\frac{(1-\zeta)}{\zeta}$. When the discount factor realized in case of a liquidity shock is small enough, banks have once again strong incentives to sell on secondary markets. They will do so when the pooling price is high enough so that a bank, receiving a liquidity shock, is willing to sell. As in the previous case, when more trading occurs on the secondary markets, leverage ratios tend to be higher and the economy response to shocks tends to be amplified. Indeed, in presence of negative shocks, higher pooling prices, increase the rents accruing to the bank, hence amplify the banks' moral hazard. Under positive shocks, secondary markets allow to free up liquidity and to exploit investment opportunities.

In the short run and since the agents in this model are risk averse, large fluctuations are welfare detrimental. The larger is the difference between the leverage ratios with and without secondary markets, the larger is the size of the inter-temporal inefficiency. Such difference is indeed a wedge which captures the worsening of the moral hazard problem under secondary markets and further distorts the allocation of investment.

\subsection{Risk Premia and Efficiency Wedges}

Given the dual moral hazard problem and the banks' preference for liquidity, the model is characterized by the presence of a number of risk premia.

First of all, there is an external finance premium which covers the costs stemming from the combined firms' and banks' moral hazard. The agency problems are mitigated by intermediation and monitoring, but this requires that part of the project returns cover for those activities. The external finance premium is given by the ratios between the combined rents accruing to the entrepreneur and the bank and the cost of financing through uninformed investors. After defining $\Xi_{t}=\frac{b}{p_{h}-p_{l}}+\frac{c}{\bar{\theta} q_{t}\left(p_{h}-p_{l}\right)}$ as the combined rents accruing to entrepreneurs and banks, we can define the external finance premium as:

$$
E F P_{t}=\frac{\Xi_{t}}{R_{t}^{h}}=\frac{1}{\frac{R_{t}}{\Xi_{t}}-1}
$$

Importantly, the external finance premium in this model behaves countercyclically: an increase in asset price, due for instance to a positive productivity shock or to a monetary easing, reduces 
the premium for external finance. The reason for the counter-cyclical behavior stems from the fact that an increase in asset prices renders both, firms' and banks' incentive compatibility constraints less stringent, thereby mitigates the agency problems.

In presence of secondary markets the combined rents are given by $\Xi_{t}^{s}=\frac{b}{p_{h}-p_{l}}+\frac{c}{q_{t}\left(p_{h}-r\right)}$. Even in this case the external finance premium is counter-cyclical. In addition and, as explained in the previous section, the external finance premium (which is directly related to the leverage ratio) is larger when $r<p_{l}$. In this case, indeed, banks' moral hazard problems are more severe and their incentive to sell toxic assets are stronger. This implies that the required external finance premium increases.

Finally, in presence of secondary markets there is also an additional liquidity premium. Adverse selection implies, that assets in the secondary market are sold at discounted price:

$$
r=\frac{\zeta p_{h}}{1-p_{h}+\zeta p_{h}}<p_{h}
$$

In a recent paper Gilchrist and Zakrajsek [26] have measured the excess bond premium as the size of the corporate bond spread in excess of default risk. They interpret such measure as a proxy for the liquidity premium. Interestingly they found that during the 2007-2008 crisis such premium had increased much more sharply than the corporate bond premia. An evidence which squares with the implications of the present model.

\subsection{Bank Capital Ratios}

Bank capital in this model is optimally determined to mitigate the severity of the banks' moral hazard. The endogenously determined bank capital demand implies the following capital adequacy ratios:

$$
b k_{t}=\frac{B K_{t}}{B K_{t}+D_{t}}=\frac{c\left(1+r_{t}^{n}\right)}{c\left(1+r_{t}^{n}\right)+R_{t}^{e} q_{t}\left(p_{h}-p_{l}\right)\left(1-r_{t}^{m}\right)}
$$

As we shall see later on in the dynamic simulations, the above capital adequacy ratio behaves pro-cyclically: expansionary shocks, by increasing asset prices, relax the incentive compatibility constraints, thereby require lower bank capital ratios. The more so, the lower is the monitoring cost. 
Bank capital ratios in presence of secondary markets are given by:

$$
b k_{t}^{s}=\frac{B K_{t}^{s}}{B K_{t}^{s}+D_{t}^{s}}=\frac{c\left(1+r_{t}^{n}\right)}{c\left(1+r_{t}^{n}\right)+R_{t}^{e, s} q_{t}\left(p_{h}-r\right)\left(1-r_{t}^{m}\right)}
$$

To the extent that $r<p_{l}$, an expansionary shock reduces bank capital ratios by more in presence of secondary markets. The possibility of contrasting liquidity shocks through loan sales on secondary market, reduces bank' incentives to maintain high capital adequacy ratios. In equilibrium this reduces the incentives of banks to monitor and steepens the moral hazard problem.

\subsection{Calibration}

Household preferences and production. The time unit is the quarter. The utility function of households is $U\left(C_{t}, H_{t}\right)=\frac{C_{t}^{1-\sigma}-1}{1-\sigma}+\nu \log \left(1-H_{t}\right)$, with $\sigma=2$, as in most real business cycle literature. The parameter $\nu$ is set equal to 3 and has been chosen in such a way to generate a steady-state level of employment $H \approx 0.3$. The discount factor is set to $\beta=0.99$, so that the annual real interest rate is equal to $4 \%$. The production function is a Cobb-Douglas, $F(\bullet)=K_{t}^{\alpha}\left(H_{t}\right)^{1-\alpha}$, with $\alpha=0.3$. The quarterly aggregate capital depreciation rate $\delta$ is 0.025 , the elasticity of substitution between varieties is set to 6 .

The parametrization of the degree of price stickiness $\vartheta$, is chosen as follows. In the log-linear formulation of equation 12, the elasticity of inflation to real marginal cost (normalized by the steadystate level of output) takes the form $\frac{\varepsilon-1}{\vartheta}$. Referring to such slope allows a direct comparison with empirical studies on the New-Keynesian Phillips curve such as Gali and Gertler [23] and Sbordone [44] using Calvo-Yun approach. In those studies, the slope coefficient of the log-linear Phillips curve can be expressed as $\frac{(1-\hat{\vartheta})(1-\beta \hat{\vartheta})}{\hat{\vartheta}}$, where $\hat{\vartheta}$ is the probability of not resetting the price in any given period in the Calvo-Yun model. For any given values of $\varepsilon$, which entails a choice of the steady state level of the markup, it is possible to build a mapping between the frequency of price adjustment in the Calvo-Yun model $\frac{1}{1-\hat{\vartheta}}$ and the degree of price stickiness $\vartheta$ in the Rotemberg setup. The recent New Keynesian literature has usually considered a frequency of price adjustment of four quarters as realistic. Recently, Bils and Klenow [9] have argued that the observed frequency of price adjustment in the US is higher, in the order of two quarters. As a benchmark, we parameterize $\frac{1}{1-\hat{\vartheta}}=4$, which implies $\hat{\vartheta}=0.75$. Given $\varepsilon=6$, the resulting stickiness parameter satisfies $\vartheta=\frac{Y \hat{\vartheta}(\varepsilon-1)}{(1-\hat{\vartheta})(1-\beta \hat{\vartheta})} \approx 30$, where $Y$ is steady-state output. 
Banks. The parameters characterizing the contract among bankers, depositors and entrepreneurs, $p^{h}, p^{l}, c, R, b$, and their survival probability, $\gamma^{e}, \gamma^{b}$, are calibrated as follows. The $p^{h}$ is set equal to 0.9 so that the quarterly failure rate of entrepreneurs is $0.97 \%$ as in Bernanke, Gertler and Gilchrist [10] and Carlstrom and Fuerst [12]. The remaining parameters are set so as to induce the following steady state values: 1 . A capital adequacy ratio, $\frac{B K}{B K+D}$, of $19 \%$ in line with BIS data [8]; 2. a ratio of investment over output, $\frac{I}{Y}$, of $0.15 ; 3$. a capital over output, $\frac{K}{Y}$, of 6.6 in accordance with $\mathrm{RBC}$ literature; 4. a ratio of investment over entrepreneurial net worth of, $\frac{I}{N W}$, equal to 2 in accordance with Bernanke, Gertler and Gilchrist [10]; 5. a return on bank assets (ROA), $R^{b}$, of $16 \%$ in accord with the data from the American Bankers Association for the 2000. Such an indirect calibration strategy delivers the following parameter values: $p^{l}=0.66, c=0.05, R=1.21, b=0.16, \gamma^{e}=0.78, \gamma^{b}=0.72$. Finally in the benchmark case the stochastic discount factor is calibrated as follows: $\theta$ is set to 0.99 and $\zeta$ is set to 0.5 . Robustness tests will be done to evaluate the impact of liquidity shocks.

Shocks. Total factor productivity is assumed to evolve as:

$$
A_{t}=A_{t-1}^{\rho_{\alpha}} \exp \left(\varepsilon_{t}^{\alpha}\right)
$$

where the steady-state value $A$ is normalized to unity (which in turn implies $\omega_{m}=1$ ) and where $\varepsilon_{t}^{\alpha}$ is an i.i.d. shock with standard deviation $\sigma_{\alpha}$. In line with the real business cycle literature, we set $\rho_{\alpha}=0.95$ and $\sigma_{\alpha}=0.008$. Log-government consumption is assumed to evolve according to the following process:

$$
\ln \left(\frac{G_{t}}{G}\right)=\rho_{g} \ln \left(\frac{G_{t-1}}{G}\right)+\varepsilon_{t}^{g}
$$

where $G$ is the steady-state share of government consumption (set in such a way that $\frac{G}{Y}=0.25$ ) and $\varepsilon_{t}^{g}$ is an i.i.d. shock with standard deviation $\sigma_{g}$. We follow the empirical evidence for the U.S. in Perotti [38] and set $\sigma_{g}=0.0074$ and $\rho_{g}=0.9$.

The monetary policy shock is an additive disturbance to the nominal interest rate set by the monetary authority. The monetary policy shock is assumed to have zero persistence. The shocks is set to 0.006 . Such calibration is consistent with estimates of the interest rate process conducted by Rudebusch [43] and Angeloni, Faia and Lo Duca [4] 


\section{Quantitative Properties of the Model in Absence of Secondary Markets}

In this section we examine the response of the model in absence of secondary markets to three main shocks: productivity, government expenditure and monetary policy.

Figure 2 shows impulse responses of selected variables to a productivity shock. As it is standard in New Keynesian models, output increases while inflation decreases. Due to sticky prices employment decreases: an improvement in productivity induces firms to save on labour hours. The increase in productivity also brings about an increase in investment demand and in the return on capital. Let's now examine the banking and the financial sector. First, due to the increase in both, the investment demand and the return from investment, both entrepreneurial net worth and bank capital increase (though the bank capital ratio decreases marginally). As the scale of required investment increases, both the entrepreneur and the bank increase their stake into the projects. The increase in asset prices reduces the severity of the moral hazard problem, as it is easier to meet the incentive compatibility constraints for both the bank and the entrepreneur. This implies that the share of returns from the project accruing to the bank falls, while the share accruing to the outside investors increases. Overall, banks and investment returns are negatively correlated. The bank capital ratio decreases on impact, hence it behaves pro-cyclically, as it would do under a Basel II-type capital requirement, but here as an endogenous result of market discipline: as the moral hazard problem becomes less severe, capital adequacy ratios are relaxed to free up liquidity.

Figure 3 shows impulse responses to a government expenditure shock. Output increases, while households consumption and private investment decline due to the crowding out effect. The ensuing fall in inflation triggers a fall in the nominal interest rate from the Taylor rule. This brings about an increase in deposits, which in turn determines a fall in the amount of entrepreneurial net worth and bank capital needed to satisfy investment demand. Overall, available funds for investment decrease. This induces a fall in investment and in the asset price, which increases the severity of the moral hazard problem therefore inducing an increase in the returns accruing to the bank and a fall in the returns accruing to depositors. Contrary to the productivity shocks, capital adequacy ratios behave counter-cyclically under this shock. This is again the result of market discipline; as the price of capital declines it is more difficult to meet the incentive compatibility constraint, hence 
bankers must increase their stake in the project.

Figure 4 shows impulse responses of selected variables to a monetary policy tightening. As expected, output, consumption and inflation fall. The increase in the nominal interest rate reduces the return accruing to depositors, as their outside option is less attractive. On the other side, the ensuing fall in asset prices strengthens the moral hazard problem and increases the returns accruing to the bank. Contractionary monetary policy reduces investment demand. The ensuing fall in asset prices reduces the accumulation of both, entrepreneurial wealth and bank capital. Such reduction, coupled with a more severe moral hazard problem, induces an increase in the capital adequacy ratios, which behave pro-cyclically under this shock.

\subsection{The Role of Secondary Markets}

Quantifying the cost of liquidity is an essential element in judging the possible benefits of secondary markets, which allow banks to reduce the costs of capital recycling. I assume that a large liquidity shock occurs so that the discount factor may become $\theta=0.3$. This can occur under two different probability levels: $\zeta=0.9$ or $\zeta=0.2$. In the first case the liquidity shock plays a significant role for the dynamic, as the expected discount factor is still very low. The opposite is true in the second case.

Figure 5 shows the effects on banks' return and the capital ratio of a positive productivity shock under the two parameter sets, high probability of liquidity shocks (solid line) or low probability of shock (crossed line). A higher discount factor, which occurs when the probability of a liquidity shock is high, reduces the expected return to the bank. A bank receiving lower rents has a larger incentive to monitor, hence the moral hazard problem becomes relatively less severe. In absence of secondary market, the bank must commit to maintain the resources invested in the project until completion. Such a commitment increases the incentive for the bank to adopt proper monitoring activities, which implicitly reduces moral hazard. As a result, the bank capital ratio falls by more under a high probability of a liquidity shock, as this allows to free up liquidity.

Figures 6,7 , and 8 present impulse responses to the three usual shocks - positive productivity, expansionary fiscal expenditure, contractionary monetary policy. In each panel the impulse response without secondary market is plotted against that of the model with secondary market.

Under a productivity shock, the response of output, investment and inflation and all other 
macro variables is amplified in the model which allows for credit risk transfer. The exceptions are consumption and employment. The presence of secondary markets allows to improve liquidity in the economy. This lowers endogenously interest rates and smooths consumption and employment over time.

Market for credit risk transfer have several effects. First, since they provide possibility for capital recycling, they also require lower bank capital ratios as device for market discipline. Under a positive productivity shock, capital ratios decline more than in the benchmark case. Second, the bank can face better unexpected liquidity shocks when they occur. Hence banks' expected returns are higher, but react less to the shock. Higher returns to banks also imply that, on average, it is less likely to meet the incentive compatibility constraint for the bank. This implies that in equilibrium the bank has lower incentives to monitor and higher incentives to take up risk. As a result of this investment, asset prices and output are significantly more volatile.

The responses to the other two shocks are consistent with the remarks just made. Note first that, in the case of a fiscal shock, the relatively stronger crowding out effect on investment when secondary markets are allowed, generates a more muted output response (no amplification of output takes place in this case), despite the lower decline in consumption. Under a monetary policy shock, the amplification effect on output is small under the given parametrization. Investment declines significantly more in presence of active credit markets when monetary policy is tightened, for reasons similar to those explained, but the profile of consumption is virtually identical in the two models, hence reducing the percentage effect on output.

\section{Conclusions}

This paper constructs a DSGE model with banks that operate according to the originate to distribute model of banking. The model is compared with the case in which banks operate according to the traditional "originate to hold " model to appreciate the effects on the macroeconomy of secondary markets for credit risk transfer.

The analysis shows that the presence of secondary markets for credit risk transfer allows to free up bank capital and tends to amplify the dynamic of all macro variables, particularly the financial variables. In this context asset price shocks lead to financial exuberance. This is so since secondary 
markets offer a possibility of capital recycling that reduces the incentives of the bank to monitor and allows to take up more risk.

The model presented can be used to answer a variety of questions related to optimal monetary policy, optimal regulatory policy and to the interaction between the risk allocation of banks' portfolio and the macro dynamics. All this is left for future research. 


\section{References}

[1] Adrian, Tobias and Markus Brunnermeier , (2009). "CoVaR". Mimeo, Princeton University.

[2] Allen, F. and D. Gale, (1988) "Optimal Security Design". The Review of Financial Studies, $1: 229-63$.

[3] Angeloni, Ignazio and Ester Faia, (2009). "A Tale of Two Policies: Prudential Regulation and Monetary Policy with Fragile Banks". Kiel IfW w.p.

[4] Angeloni, Ignazio, Ester Faia and Marco Lo Duca, (2010). "Risk Taking and Monetary Policy". BRUEGEL w.p.

[5] Ashcraft, Adam B. and Til Schuermann, (2008). "Understanding the Securitization of Subprime Mortgage Credit". Wharton Financial Institutions Center Working Paper No. 07-43.

[6] Behr, P. and S. Lee, (2005). "Credit Risk Transfer, Real Sector Productivity and Financial Deepening". Manuscript, Goethe University Frankfurt.

[7] Bank of International Settlements, (2005). "Credit risk Transfer, Committee and the Global Financial System". Basel.

[8] International Convergence of Capital Measurement and Capital Standards: a Revised Framework, Comprehensive Version (BCBS).

[9] Bils M. and P. Klenow (2004), "Some Evidence on the Importance of Sticky Prices", Journal of Political Economy, October.

[10] Bernanke, B., M. Gertler and S. Gilchrist (1999). "The Financial Accelerator in a Quantitative Business Cycle Framework, " in J. Taylor and M. Woodford (eds.), Handbook of Macroeconomics, Elsevier Science, pp. 1341-1393.

[11] Brunnermeier, Markus K. (2008) "Deciphering the Liquidity and Credit Crunch 2007-08." Journal of Economic Perspectives, 2009, 23(1). 
[12] Carlstrom, Charles and Timothy Fuerst, (1997). "Agency Costs, Net Worth and Business Cycle Fluctuations: a Computable General Equilibrium Approach". American Economic Review, 87, 893-910.

[13] Cerasi, Vittoria and Jean c. Rochet, (2008). "Solvency Regulations and Credit risk Transfer". W.p. SSRN.

[14] Chen, N.K. (2001). "Bank Net Worth, Asset Prices and Economic Activity". Journal of Monetary Economics, 48, 415-436.

[15] Chiesa, Gabriella, (2008). "Optimal Credit risk Transfer, Monitored Finance and Banks". Journal of Financial Intermediation, 17(4), 464-477.

[16] Dell' Ariccia, G. , D. Igan and L. Laeven, (2008). "Credit Booms and Lending standards: Evidence from Sub-prime Mortgage Market“. IMF w.p. 08/106.

[17] De Marzo, Peter, (2005) "The Pooling and Tranching of Securities: A Model of Informed Intermediation." Review of Financial Studies, 18, 1-35.

[18] De Marzo, Peter and Darrell Duffie, (1999) "A Liquidity-Based Model of Security Design". Econometrica, 67, 65-99.

[19] Duffie, Darrell, (2007). "Innovations in Credit risk Transfer: Implications for Financial Stability." Manuscript, Stanford University.

[20] Duffee, G. R. and C. Zhou, (2001). "Credit Derivatives in Banking, Useful Tools for Managing risk?" Journal of Monetary Economics, 48, 25-54.

[21] European Central Bank, (2004). "Credit Risk Transfer by EU Banks: Activities, risks and Risk Management.” Report. May 2004.

[22] FicthRatings, (2004). "Global Credit Derivatives Survey". FitchRating Special Report.

[23] Galí, J. and M. Gertler (1999),"Inflation Dynamics: A Structural Econometric Analysis", Journal of Monetary Economics, vol. 44, no 2, 195-222. 
[24] Gale, Douglas and Hellwig, Martin, (1985). "Incentive-Compatible Debt Contracts: The OnePeriod Problem." Review of Economic Studies, vol. 52(4), 647-63.

[25] Gertler, Mark and Peter Karadi, (2009). "A model of Unconventional Monetary Policy". NYU.

[26] Gilchrist, Simon and Egon, Zakrajsek, (2010). "Credit Risk and the Macroeconomy". Mimeo.

[27] Gorton, G. B. and G. G. Pennacchi, (1995). "Banks and Loan Sales - Marketing Non Marketable Assets". Journal of monetary Economics, 35, 389-411.

[28] Holmström, B. and J. Tirole, (1997). "Financial Intermediation, Loanable Funds and the Real Sector". Quarterly Journal of Economics, 112, 663-691.

[29] Keys, B., T. Mukherjee, A. Seru and V. Vig, (2009). "Did Securitization Lead to Lax Screening? Evidence from Sub-prime Loans". Quarterly Journal of Economics, forthcoming.

[30] Krahnen, Jan Pieter and Günter Franke, (2007) "Default Risk Sharing between banks and markets: the case of collateralized debt obligation". Carey, M. and R. Stulz (Eds.) Risks of Financial Institutions, National Bureau of Economic Research, Chicago University Press, pp. 603-634.

[31] Leland, Hayne E. and David H. Pyle, (1977) "Informational Asymmetries, Financial Structure, and Financial Intermediation". The Journal of Finance, Vol. 32, No. 2.

[32] Meh, Césaire and Kevin Moran, (2008). "The Role of Bank Capital in the Propagation of Shocks." Working Papers 08-36, Bank of Canada.

[33] Minton, B. A., Stulz, R. M., Williamson, A. G., (2005). "How Much Banks Use Credit Derivatives to Reduce Risk?". NBER w.p. 11579.

[34] Myers, S., Majluf, N., (1984). "Corporate financing and investment decisions when firms have information that investors do not have". Journal of Financial Economics 13, 187- 221.

[35] Morrison, A. D., (2005). "Credit Derivatives, Disintermediation and Corporate Finance". Journal of Business, 78, 621-647. 
[36] Oldfield, George S. , (2000) "Making Markets for Structured Products Derivatives". Journal of Financial Economics, 57:445 .

[37] Pennacchi, G. G. (1988). "Loan Sales and the Cost of Bank Capital". Journal of Finance, 43(2), 375-396.

[38] Perotti, R. (2004), "Estimating the Effects of Fiscal Policy in OECD Countries", Mimeo IGIER Bocconi.

[39] Parlour, C. and G. Plantin, (2008). "Loan Sales and Relationship Banking". Journal of Finance, 63, 1291-1314.

[40] Parlour, C. and A. Winton, (2007). "Laying off Credit Risk: Loan Sales versus Credit Default Swap". Manuscript, University of California Berkeley.

[41] Rajan, R. (2005), "Has Financial Development Made the World Riskier?", NBER Working Paper 11728.

[42] Rotemberg, Julio (1982). "Monopolistic Price Adjustment and Aggregate Output". Review of Economics Studies, 44, 517-531.

[43] Rudebusch, Glenn D., (2002). "Term structure evidence on interest rate smoothing and monetary policy inertia." Journal of Monetary Economics, vol. 49(6), pages 1161-1187.

[44] Sbordone A. (2002), "Prices and Unit Labor Costs: A New Test of Price Stickiness", Journal of Monetary Economics Vol. 49 (2).

[45] Taylor, J.B. (2009), "The Financial Crisis and the Policy Responses: An Empirical Analysis of What Went Wrong", NBER Working Paper Series No. 14631.

[46] Woodford, Michael, 2003 Interest and Prices. 


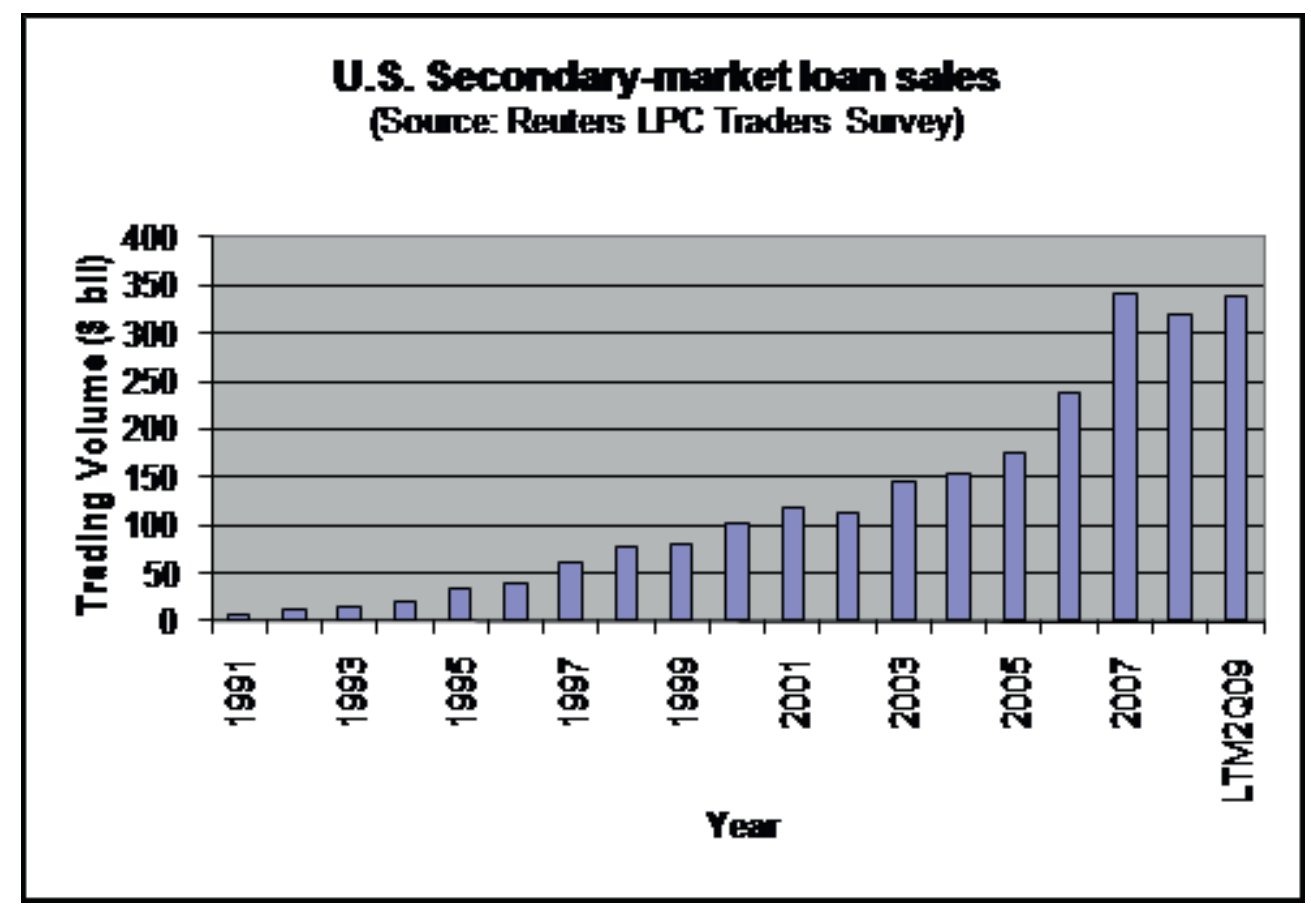



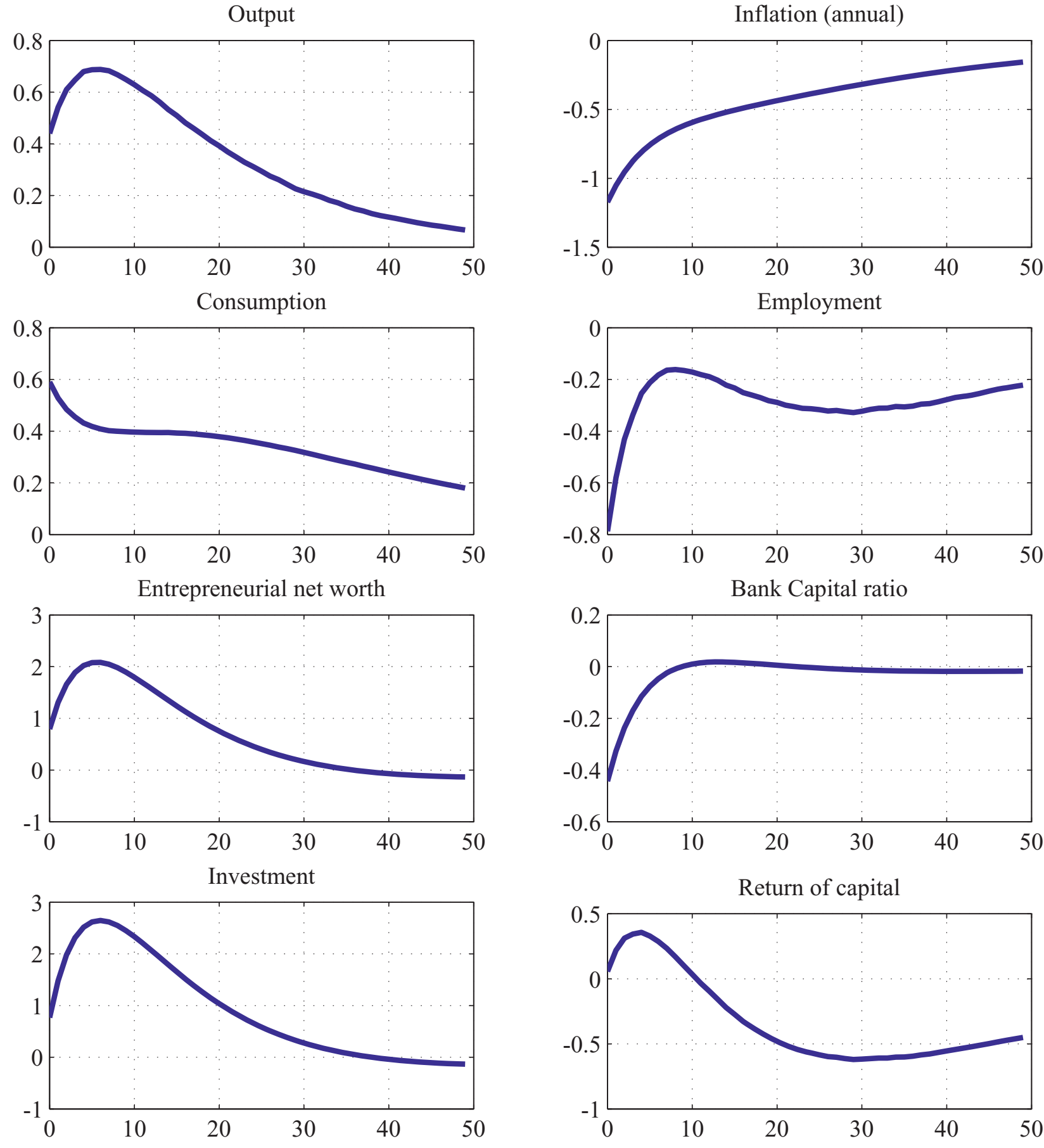

Bankers return
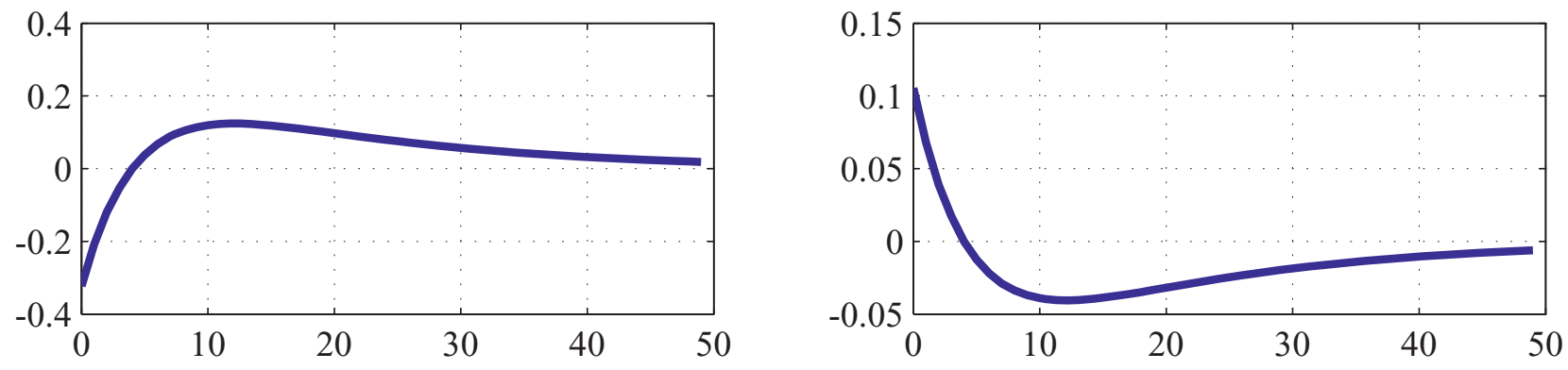
Figure 3: expansionary government expenditure shock in the model without secondary markets
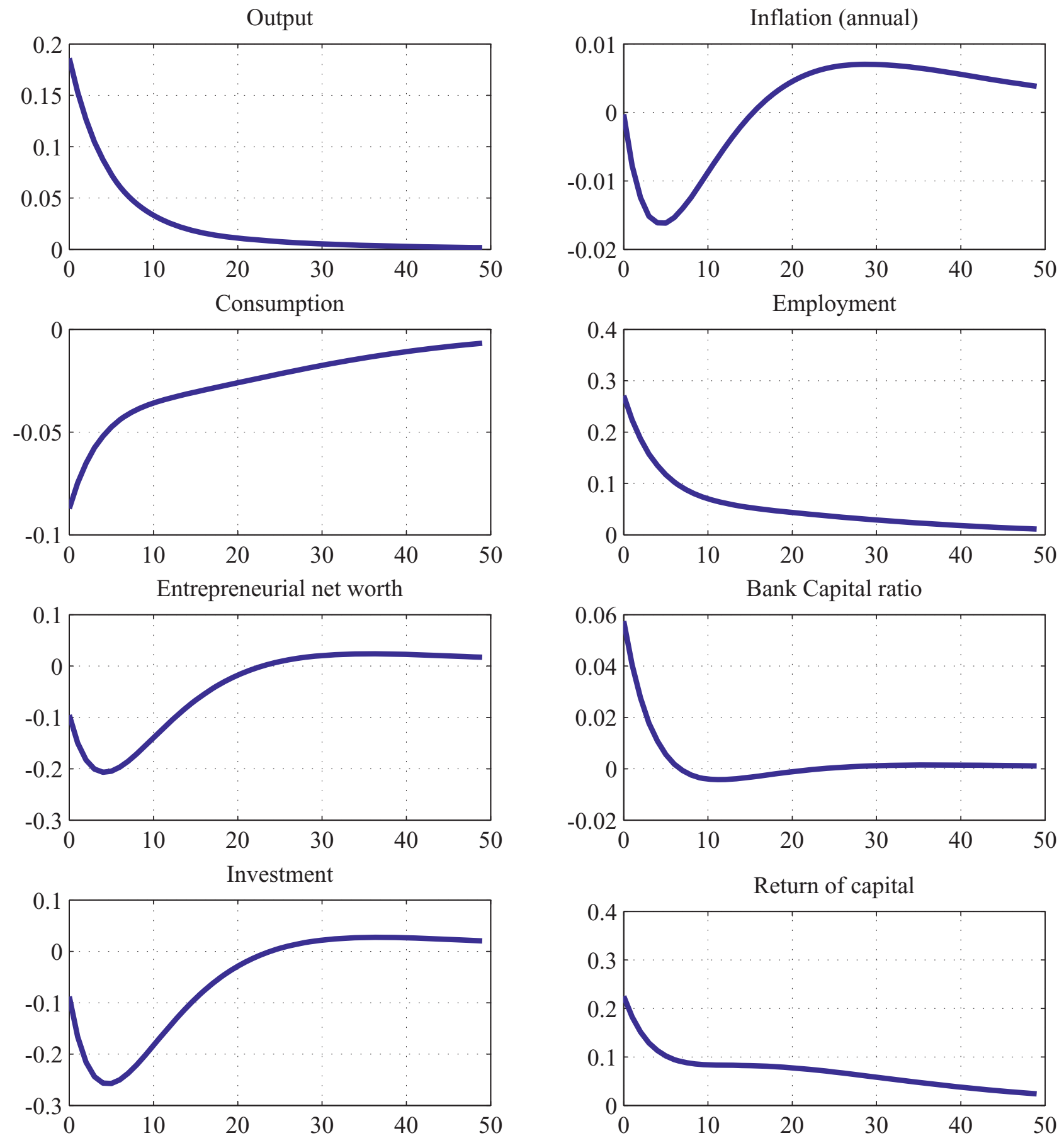

Bankers return
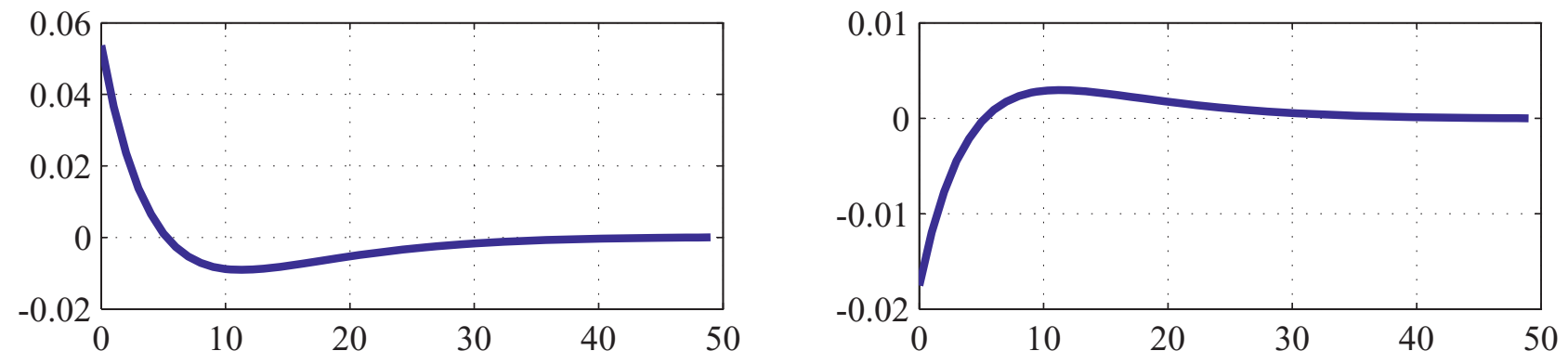
Figure 4: contractionary monetary policy shock in the model without secondary markets
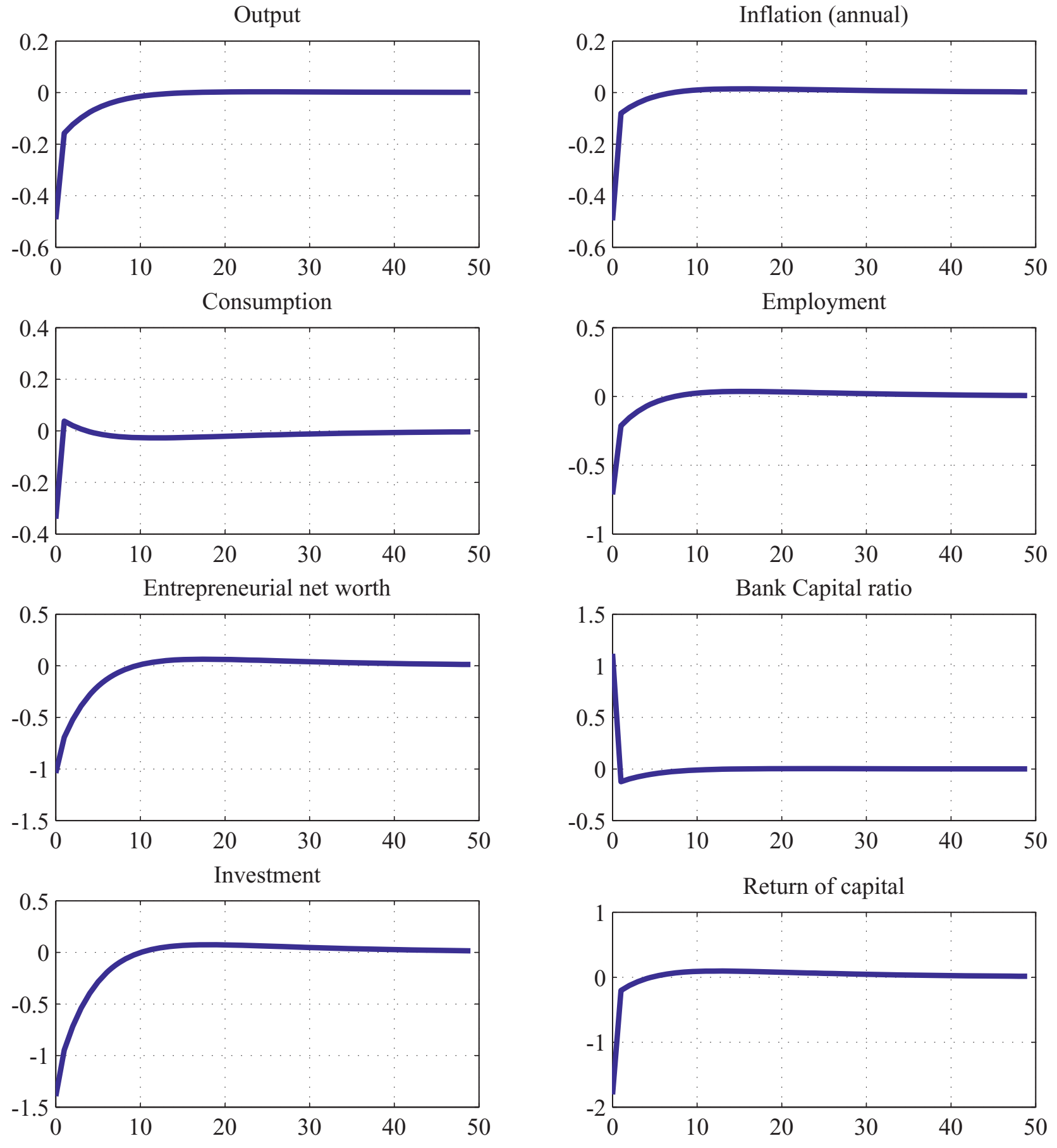

Bankers return
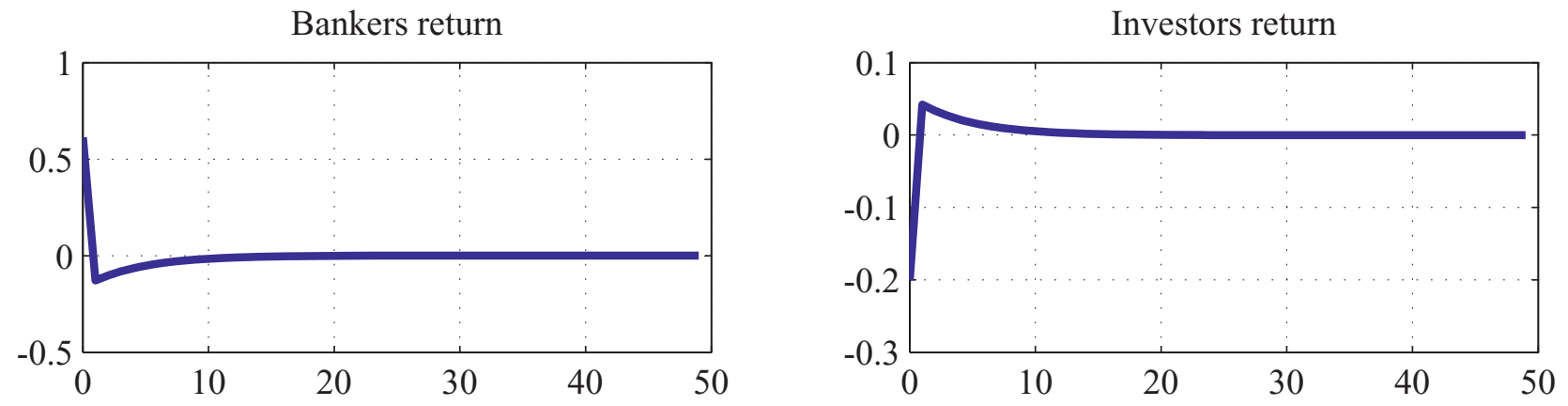
Figure 5: positive productivity shock in the model without secondary markets, high versus low probability of liquidity shock
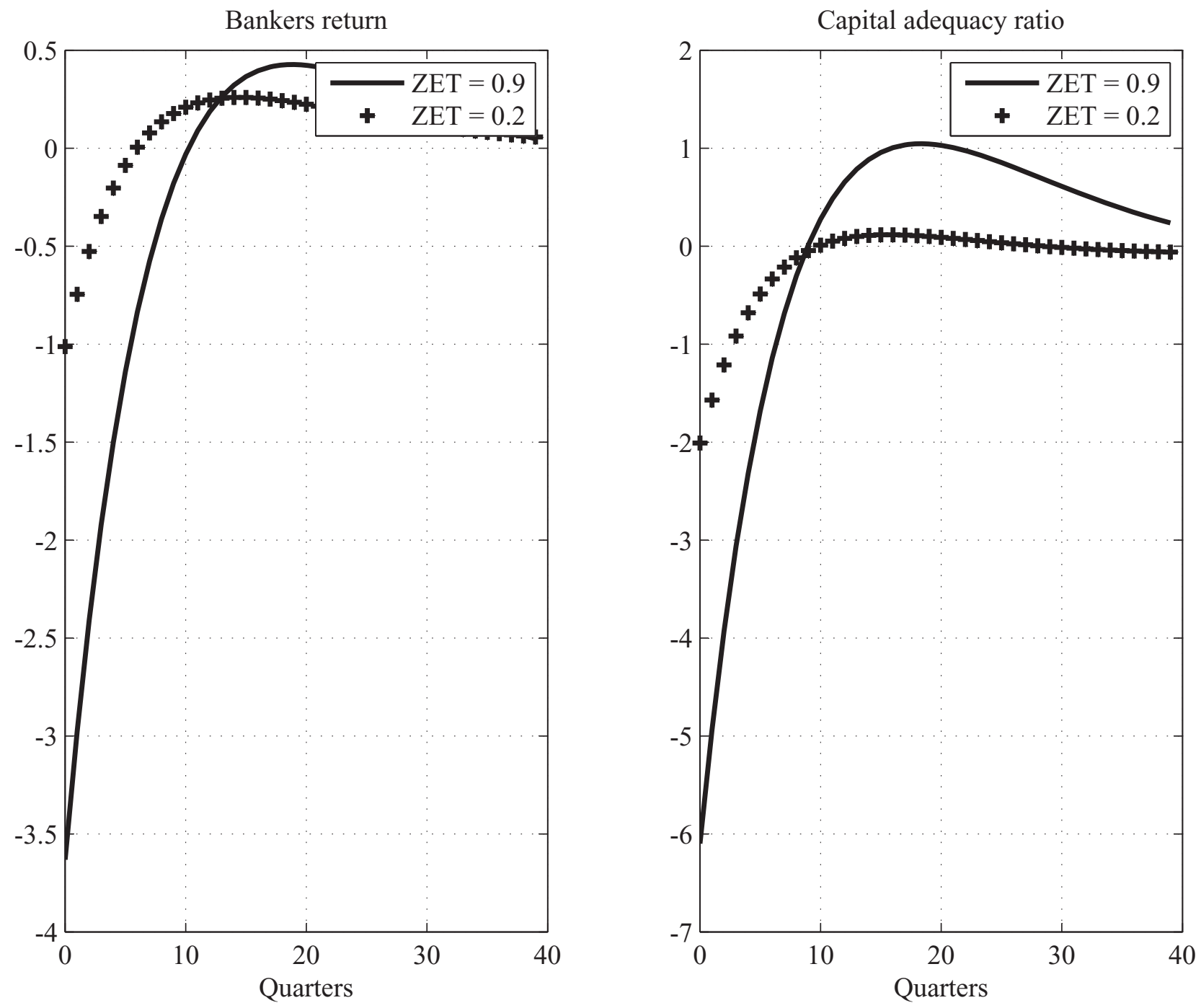
Figure 6: positive productivity shock, model with (dashed line) versus model without (solid line) secondary markets
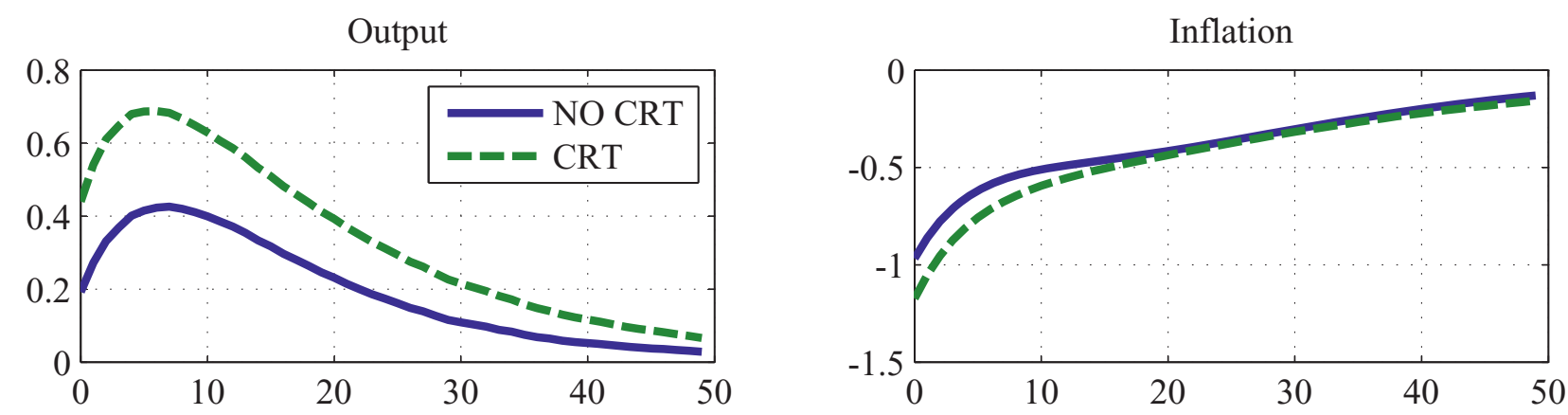

Consumption

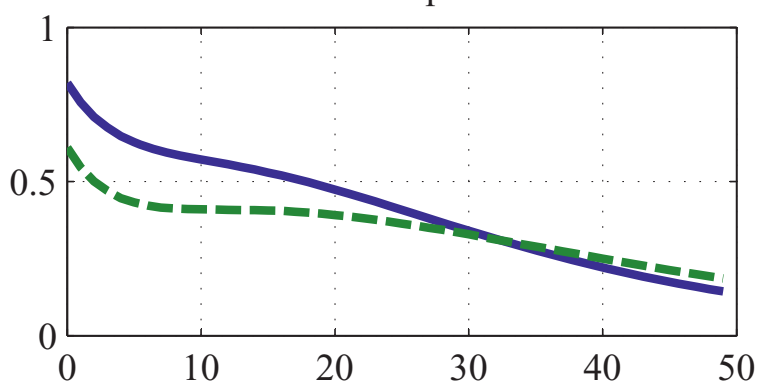

Employment

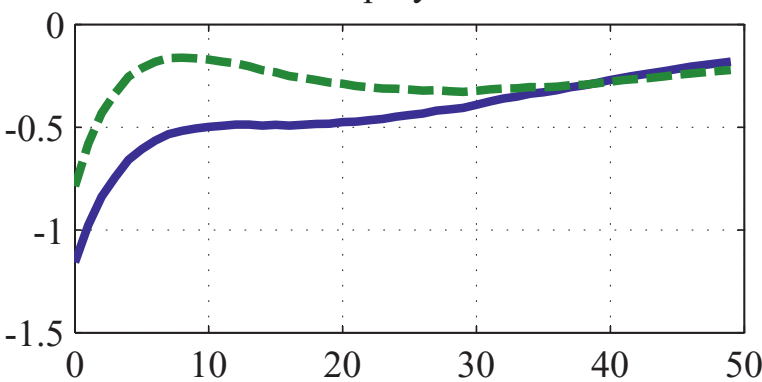

New worth

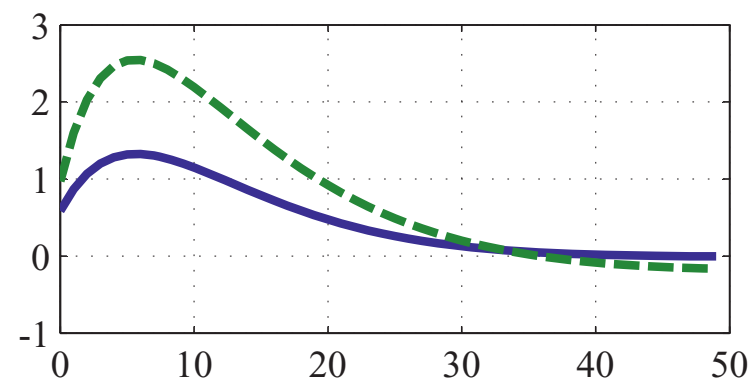

Bank capital ratio

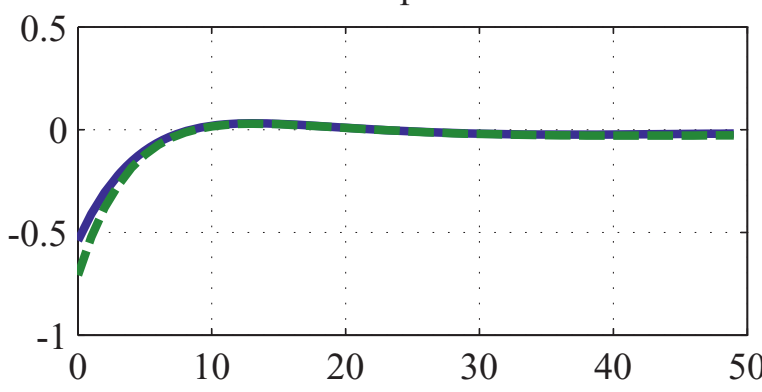

Investment

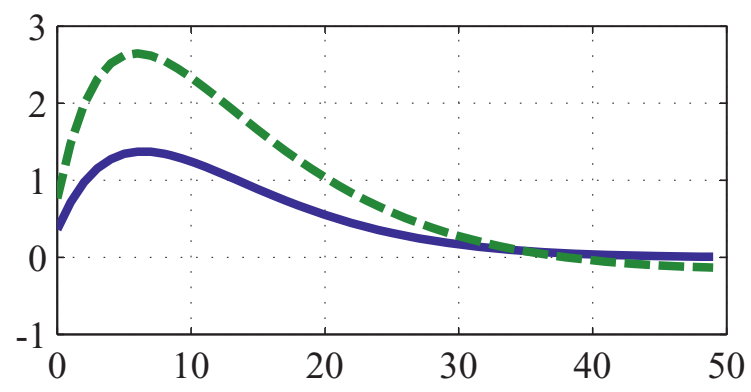

Return of capital

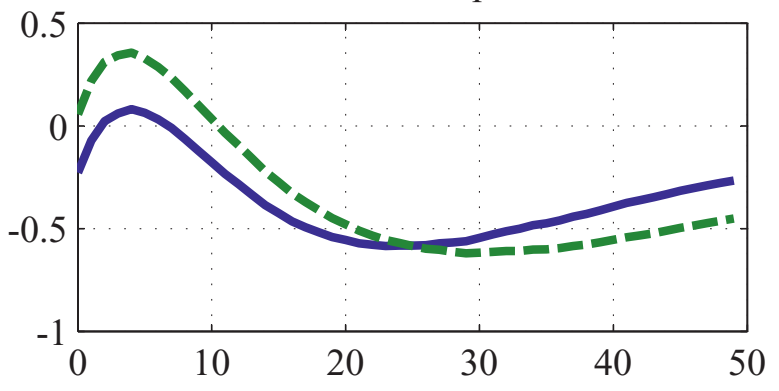

Return to banker
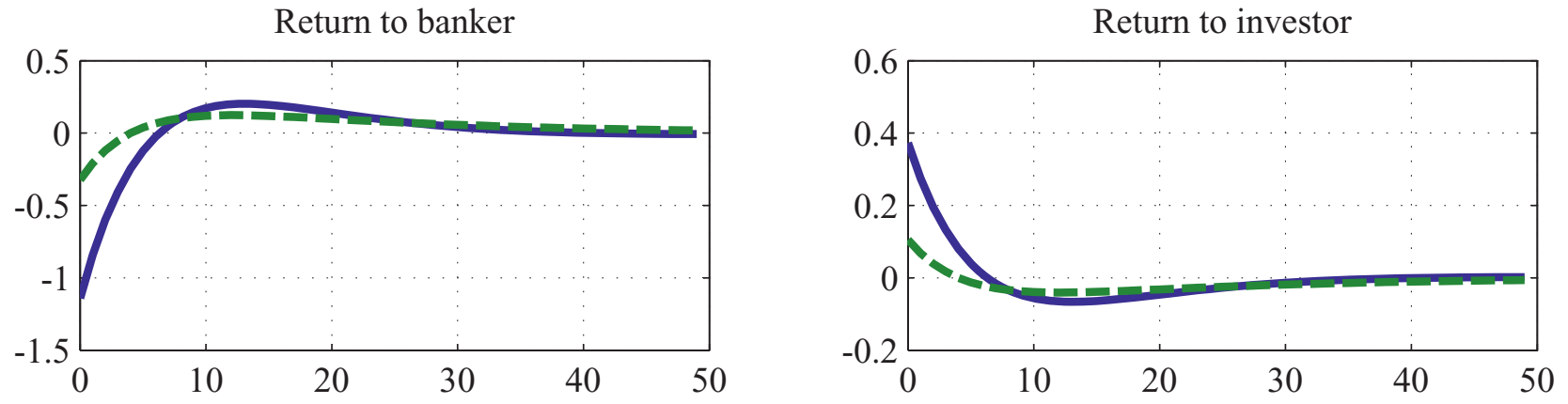

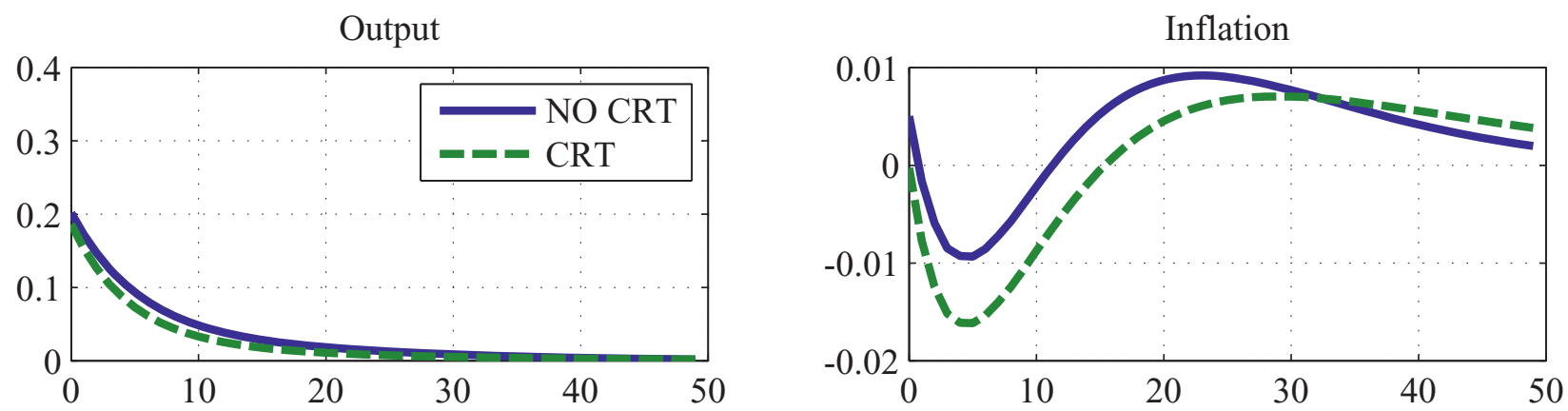

Consumption

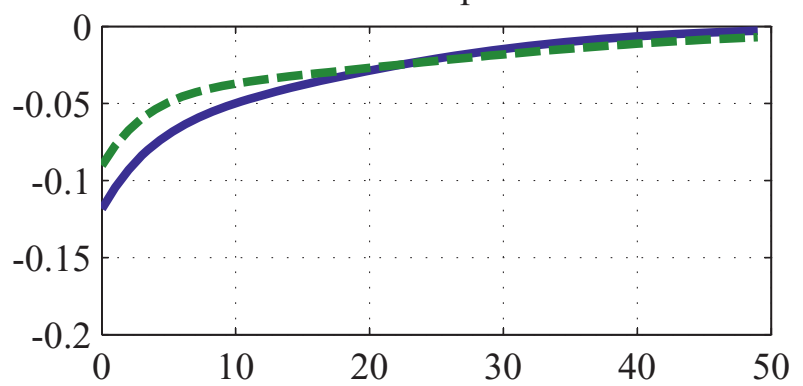

Employment

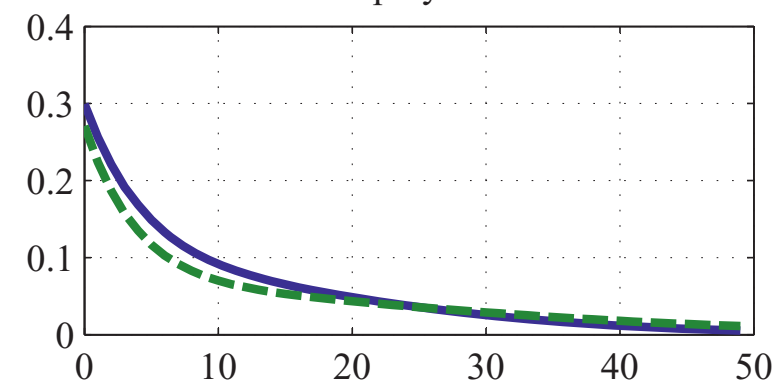

New worth

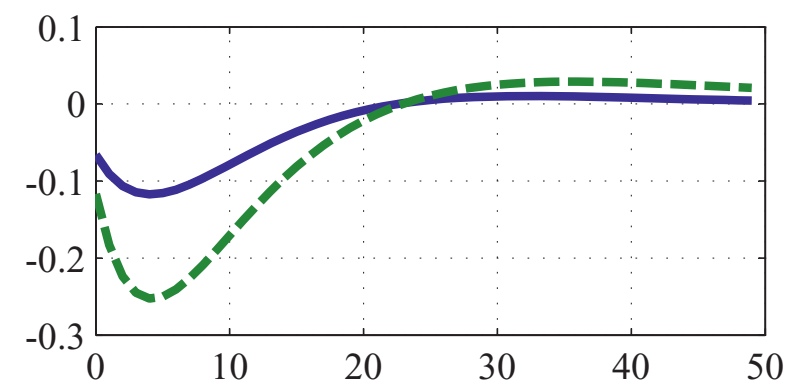

Bank capital ratio

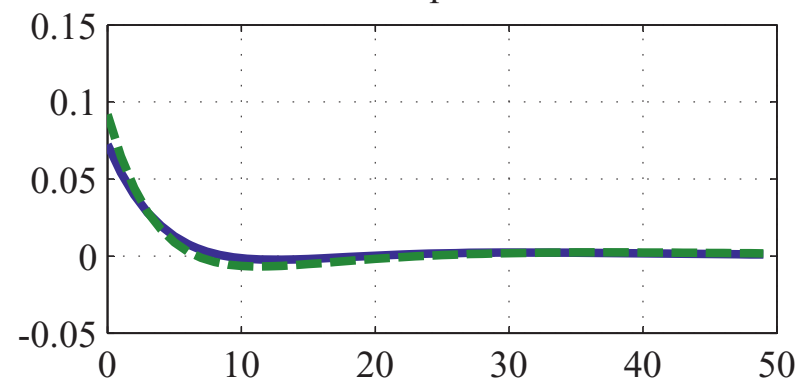

Investment

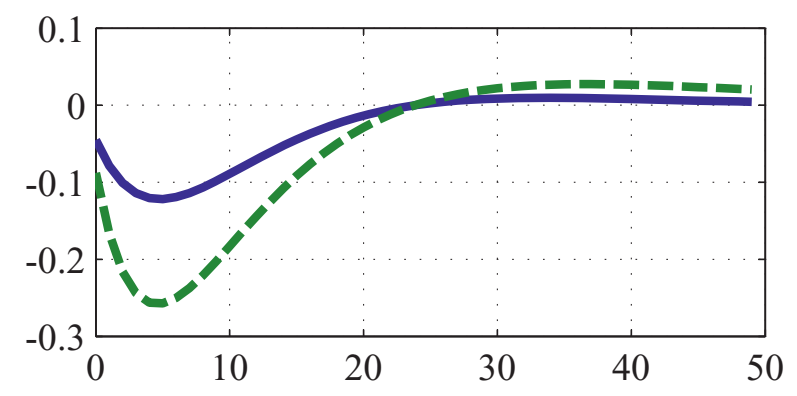

Return of capital

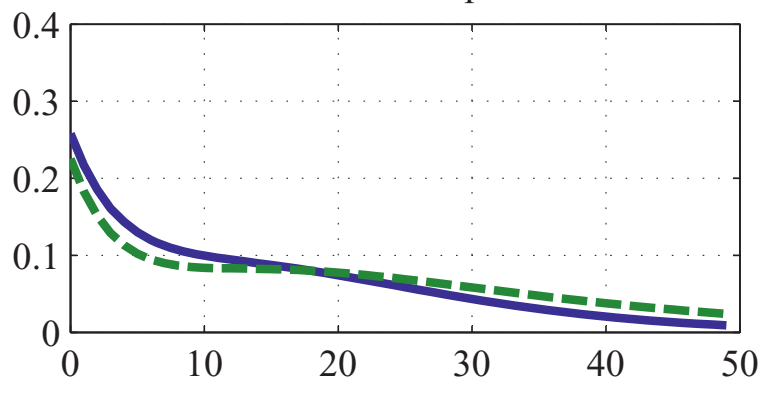

Return to banker
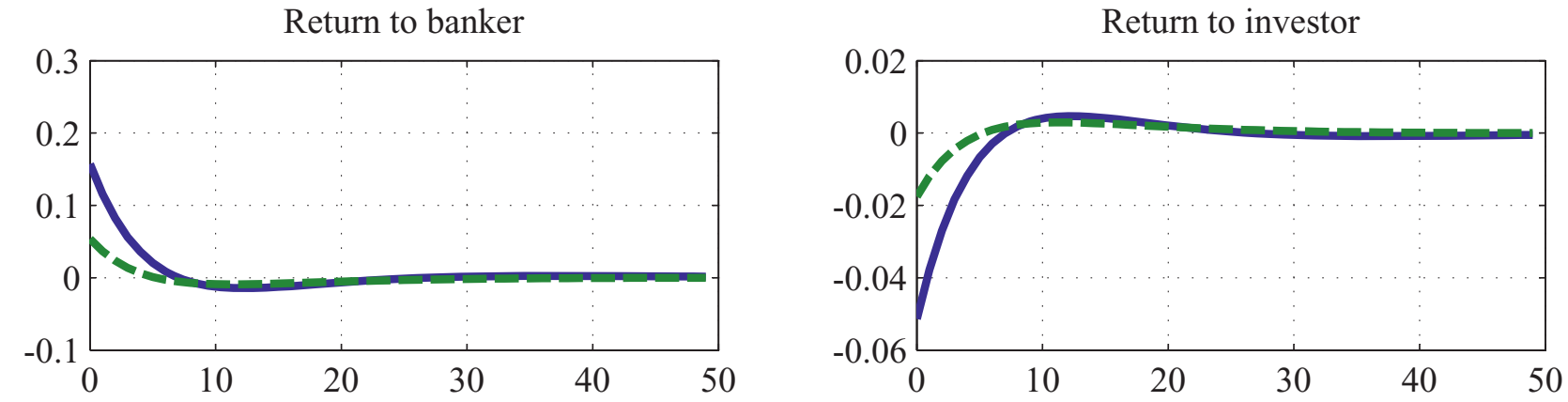
Figure 8: contractionary monetary policy shock, model with (dashed line) versus model without (solid line) secondary markets.
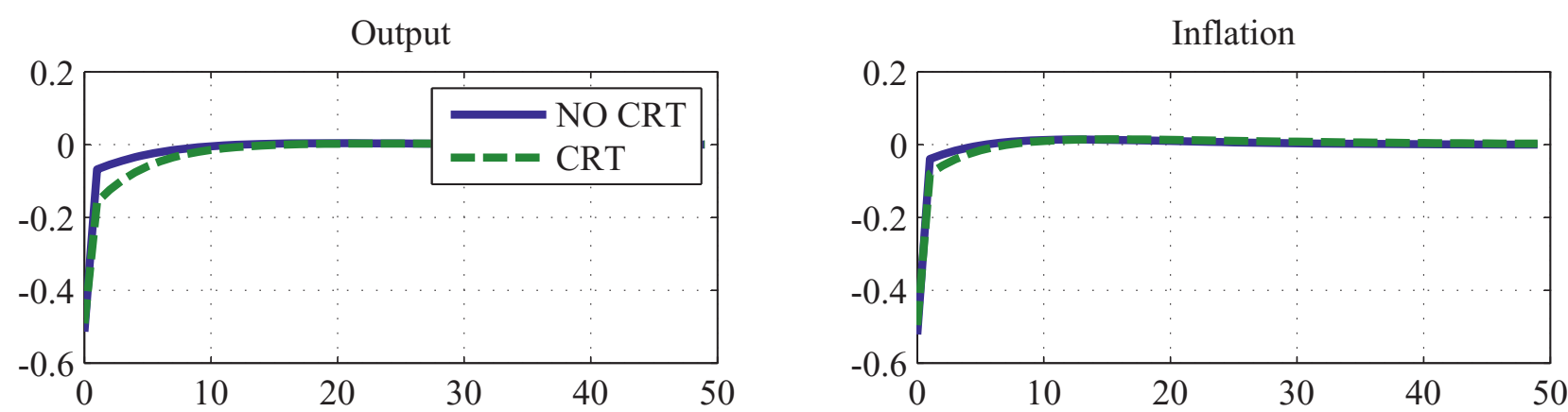

Consumption

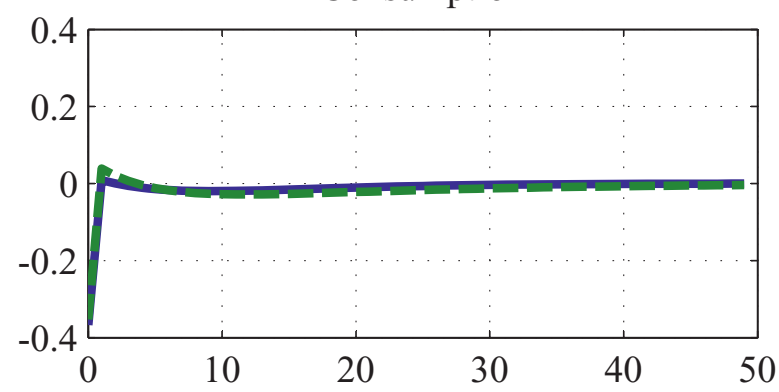

Employment

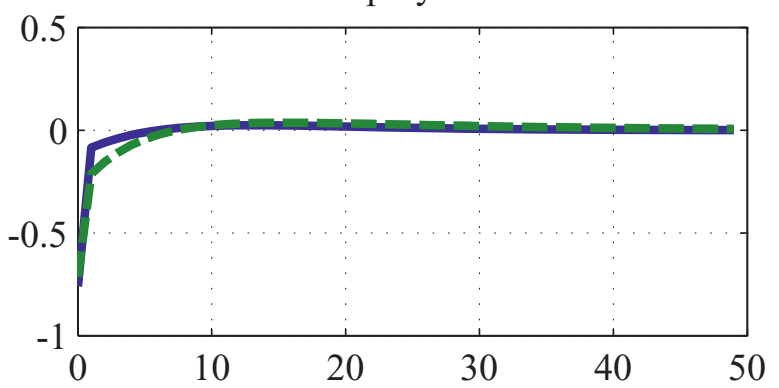

New worth

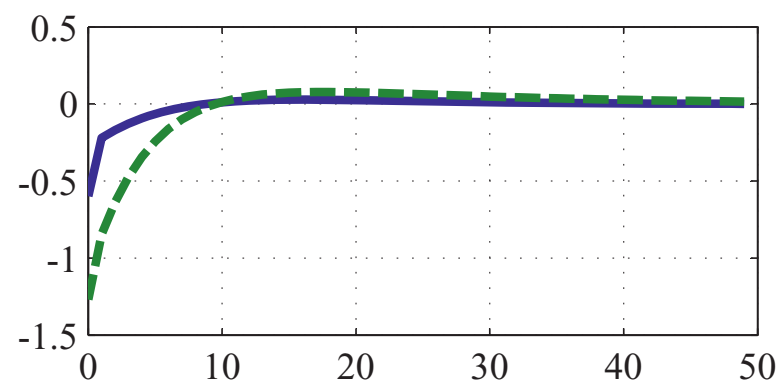

Bank capital ratio

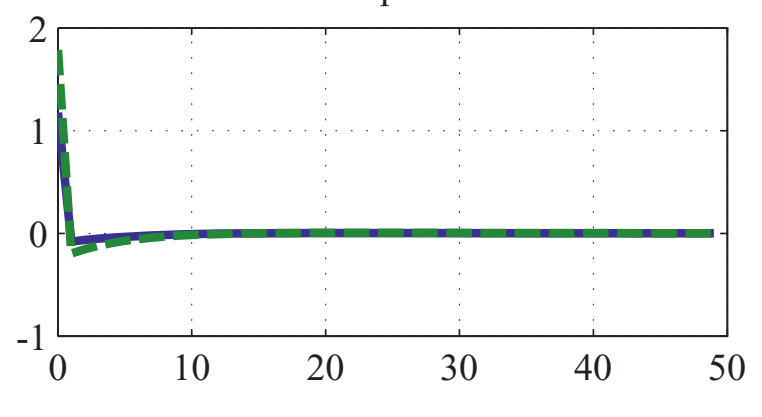

Investment

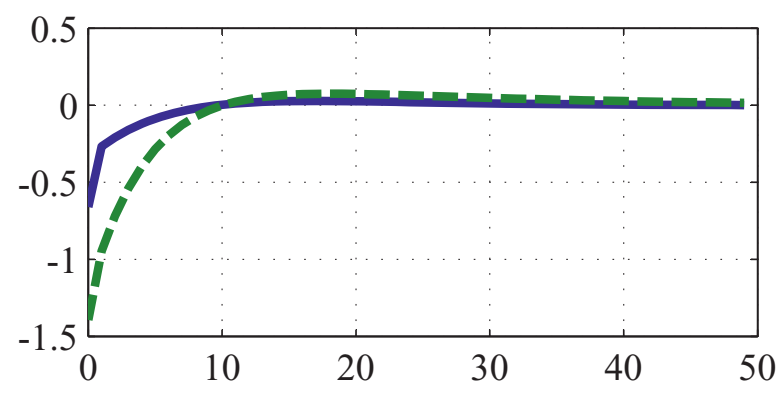

Return of capital

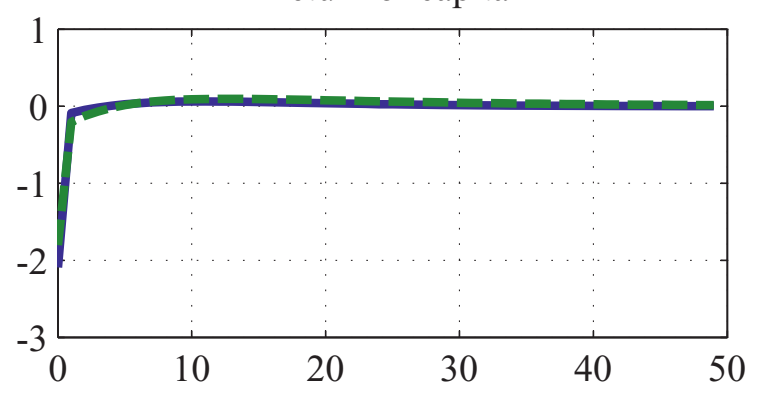

Return to banker
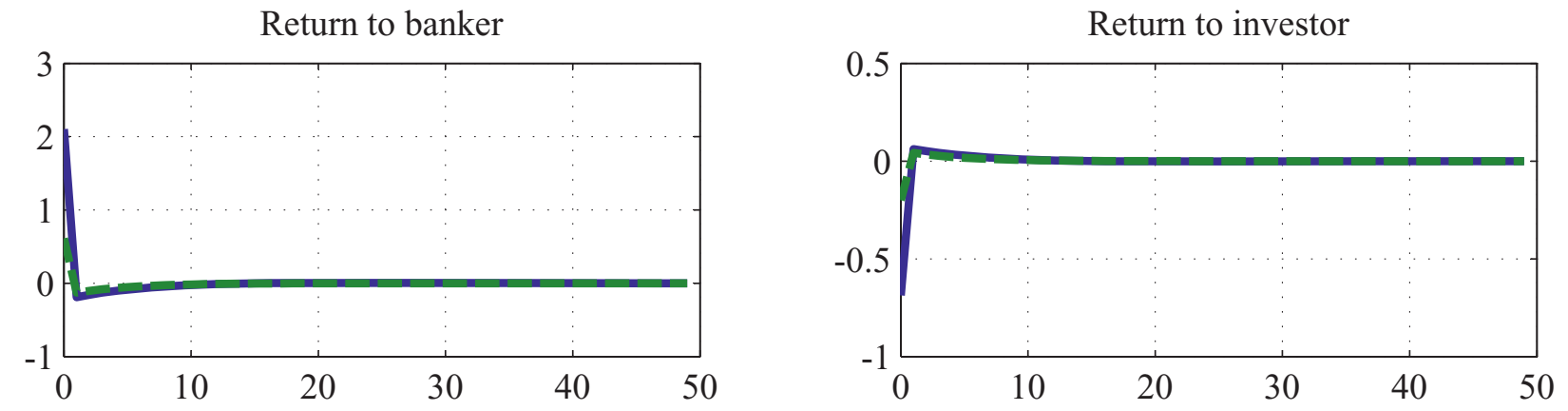
